OPEN ACCESS

Edited by:

Andrei Mocan,

Iuliu Haieganu University of Medicine

and Pharmacy, Romania

Reviewed by:

Monika Tomczykowa,

Medical University of Bialystok, Poland

Pinarosa Avato,

University of Bari Aldo Moro, Italy

*Correspondence: Aman Karim

aman.karim@yahoo.com aman.karim@numspak.edu.pk

Specialty section: This article was submitted to

Ethnopharmacology,

a section of the journal

Frontiers in Pharmacology

Received: 26 October 2020 Accepted: 01 April 2021

Published: 29 April 2021

Citation:

Haile T, Cardoso SM, de Oliveira Raphaelli C, Pereira OR, Pereira EdosS, Vizzotto M, Nora L, Asfaw AA, Periasamy $G$ and Karim A

(2021) Chemical Composition,

Antioxidant Potential, and Blood Glucose Lowering Effect of Aqueous Extract and Essential Oil of Thymus

Serrulatus Hochst. Ex Benth.

Front. Pharmacol. 12:621536.

doi: 10.3389/fphar.2021.621536

\section{Chemical Composition, Antioxidant Potential, and Blood Glucose Lowering Effect of Aqueous Extract and Essential Oil of Thymus Serrulatus Hochst. Ex Benth}

Tesfay Haile ${ }^{1}$, Susana M. Cardoso $^{2}$, Chirle de Oliveira Raphaelli ${ }^{3}$, Olivia R. Pereira ${ }^{4}$, Elisa dos Santos Pereira ${ }^{3}$, Márcia Vizzotto ${ }^{5}$, Leonardo Nora ${ }^{3}$, Adissu Alemayehu Asfaw ${ }^{6}$, Gomathi Periasamy ${ }^{1}$ and Aman Karim ${ }^{1,7 *}$

${ }^{1}$ Department of Pharmacognosy, School of Pharmacy, College of Health Sciences, Mekelle University, Mekelle, Ethiopia, ${ }^{2}$ LAQVREQUIMTE, Department of Chemistry, University of Aveiro, Aveiro, Portugal, ${ }^{3}$ Departamento de Ciência e Tecnologia Agroindustrial, Faculdade de Agronomia Eliseu Maciel, Universidade Federal de Pelotas, Pelotas, Brazil, ${ }^{4}$ Centro de Investigação de Montanha (CIMO), Instituto Politécnico de Bragança, Campus de Santa Apolónia, Bragança, Portugal, ${ }^{5}$ Embrapa Clima Temperado, Pelotas, Brazil, ${ }^{6}$ Department of Pharmaceutical Analysis and Quality Control, School of Pharmacy, College of Health Sciences, Mekelle University, Mekelle, Ethiopia, ${ }^{7}$ Department of Biological Sciences, National University of Medical Sciences, Rawalpindi, Pakistan

Thymus serrulatus, an endemic plant of Ethiopia, is traditionally used to cure various diseases and as a food ingredient. In the Ethiopian folk medicine, the decoction is orally taken as a remedy to treat diabetes and high blood pressure. The purpose of the present study was to evaluate the antioxidant and antihyperglycemic effects of the aqueous extract and of the essential oil of Thymus serrulatus. The chemical composition of the aqueous extract was determined by LC-MS and the essential oil was characterized by GC-MS analysis. Radical scavenging assays, namely scavenging of 2,2-diphenyl-1-picrylhydrazyl $\left(\mathrm{DPPH}^{\bullet}\right)$, hydroxyl $\left({ }^{\circ} \mathrm{OH}\right)$, and nitric oxide $\left({ }^{\circ} \mathrm{NO}\right)$, were used as a first approach to screen the potential antioxidant abilities of the samples. Alpha-amylase and a-glucosidase inhibitory studies were also employed to evaluate the in vitro antihyperglycemic potential of the plant. The in vivo blood glucose lowering effect of the extracts was assessed using hypoglycemic activity and the oral glucose tolerance test in normal and in streptozotocin induced diabetic mice. When compared to the aqueous extract, the essential oil showed superior radical scavenging activity, particularly for ${ }^{\bullet} \mathrm{NO}$, as well as greater inhibitory potency against $\alpha$-amylase and $\alpha$-glucosidase $\left(\mathrm{IC}_{50}=0.01 \mathrm{mg} / \mathrm{ml}\right.$ and $0.11 \mathrm{mg} / \mathrm{ml}$, respectively). Both tested samples showed a statistically significant antihyperglycemic effect. The aqueous extract at $600 \mathrm{mg} / \mathrm{kg}$ exerted maximum antihyperglycemic activity (44.14\%), followed by the essential oil (30.82\%). Body weight and glucose tolerance parameters were also improved by the samples both in normal and diabetic mice. The findings of this study support the hypothesis that aqueous extract and essential oil of $T$. serrulatus are promising therapeutic agents.

Keywords: antioxidant activity, essential oil, thyme-decoction, alpha-amylase, thymus serrulatus, alphaglucosidase, phenolic compounds profile, antihyperglycemic activity 


\section{INTRODUCTION}

Diabetes mellitus (DM), more simply called diabetes, is an endocrine disorder caused by a defect in the pancreas that prevents the production of insulin or its inefficient use by the body, resulting in hyperglycemia that, over time, leads to severe health complications (American Diabetes Association, 2009; Toelsie et al., 2013). DM is a worldwide growing epidemic disorder, with 424.9 million people affected in 2017 and an estimated $48 \%$ increase in the number of diabetic individuals by the year 2045 (European Society of Cardiology, 2019).

Chronic hyperglycemic patients live with a high risk of long-term macro- and microvascular complications, such as cardiovascular diseases, nephropathy, retinopathy, and neuropathy (Paul et al., 2020). The ability of free radicals to damage biomolecules is presently accepted to play a key role in late diabetic complications (Asmat et al., 2016). In this context, antioxidant therapy may be considered as one of the important therapeutic strategies in diabetes management (Johansen et al., 2005).

The plant materials being employed as traditional medicines are considered promising sources of new drugs to counteract many diseases, including DM (Doan et al., 2018). In addition to that, plants offer a source of dietary ingredients that affect human physiological functions in order to treat diabetes (Shori, 2015).

The genus Thymus (Lamiaceae) includes about 350 species, mostly with a high content of essential oil (Ghasemi Pirbalouti et al., 2015; Salehi et al., 2019). This is mostly distributed in Europe, Asia, and North Africa (Zarshenas and Krenn, 2015) and the vast majority of Thymus species are found in and around Mediterranean areas (Niculae et al., 2019). Two native species of thymus, namely Thymus serrulatus and Thymus schimperi, are found in Ethiopia and both are locally known as Tosign (Amharic) and Tesni/Thasne (Tigrigna) (Damtie and Mekonnen, 2015).

Thymus serrulatus Hochst. Ex Benth is a much-branched perennial subshrub endemic to Ethiopian highlands (2000-4000 m. a.s.l.) of Semien Shoa, Tigray, and Wollo (Damtie and Mekonnen, 2015; Melka et al., 2016). It is restricted to the northern parts of the country and is reported to be found in Alamata and Ofla (Tigray), Yilmana Densa (West Gojjam), and Tarmaber (North Shewa) (Damtie et al., 2017). In turn, T. serrulatus is found in different parts of Ethiopia. This specie is commonly used to flavor tea, coffee, and different kinds of stew (Asfaw et al., 2000). Traditionally, the fresh or dried whole parts, leaves, or flowers of the plant are crushed and drunk as a tea to treat different illnesses, including diabetes, high blood pressure, general pain syndrome, abdominal pain, intestinal parasites, and renal disease (Meresa et al., 2017). It is also used for the treatment of headache, earache, and liver disease (Melka et al., 2016). The essential oil of T. serrulatus is also used for medicinal purposes as antiseptic, antifungal, and vermifuge properties (Asfaw et al., 2000). The bioactive potential of the plant is supported by previous experimental studies, which include antihelimenthic, antibacterial, fungicidal (Damtie and Mokonen, 2015), diuretic (Melka et al., 2016), vasodilatory (Geleta et al., 2015), and hepatoprotective (Damtie et al., 2017) activity.
Distinct studies previously reported in vivo/animal assays with thyme species (Li et al., 2019). In addition, the profile of phenolic compounds (Afonso et al., 2020) and of essential oils (Tohidi et al., 2019) from Thymus species originating from different parts of the world have been reported. Still, to our knowledge, there is no report concerning the phytochemical composition and antidiabetic effect of $T$. serrulatus. Therefore, this study evaluated the chemical composition, antioxidant potential, and the antihyperglycemic effects of a decoction and of essential oils from $T$. serrulatus origin.

\section{MATERIALS AND METHODS}

\section{Chemicals}

The phenolic compounds salvianolic acid B, ferulic acid, apigenin-O-glucoside, eriodictyol-7-O-glucoside, quercetin-7$O$-glalactoside, luteolin-7-O-glucoside, and rosmarinic acid (obtained from Extrasynthese, Genay Cedex, France) were used as standards for the phenolic characterization of the aqueous extract. Thymol 99\% (Sigma Aldrich, Germany) was also used as a standard reference to confirm the identity of the compound in the essential oil. Glibenclamide (Alfa aesar, Great Britain), acarbose (Bayer Pharma AG, Leverkusen, Germany), and quercetin (Sigma- Aldrich, St. Louis, MO, United States) were used as reference standard for the in vivo antidiabetic activity, in vitro digestive enzyme inhibitory activity, and radical scavenging activity tests of the samples, respectively.

\section{Plant Materials}

The sample of $T$. serrulatus aerial parts was collected during flowering season from Emba Alaje mountain area, Emba Alaje District of South Tigray, Ethiopia (located at $13^{\circ} 00^{\prime}$ North latitude and $39^{\circ} 20^{\prime}$ East longitude) in the month October 2018. The plant was authenticated by Getinet Masresha (taxonomist) at the Department of Biology, University of Gondar, Ethiopia. A voucher specimen (TH-001/2011) was placed for reference in the University of Gondar's herbarium.

\section{Preparation of the Aqueous Extract}

The aqueous extract was prepared by decoction, according to Afonso et al. (2017), with adaptations. Aerial parts T. serrulatus were shed dried and then powdered. The powdered plant material $(20 \mathrm{~g})$ was mixed with distilled water $(400 \mathrm{ml})$ and then boiled for $15 \mathrm{~min}$, left to cool for $5 \mathrm{~min}$, and filtered through Whatman grade 1 filter paper, using a pressurized suction filtration system. Upon concentration in vacuo at $40^{\circ} \mathrm{C}$, the filtrate was defatted with $\mathrm{n}$-hexane $(1: 1 \mathrm{v} / \mathrm{v})$. The resulting aqueous extract was freezedried, sealed, and kept in a refrigerator for further use. A fresh stock solution was prepared for the experiment whenever required.

\section{Extraction of the Essential Oil}

The fresh aerial parts (250 g) of T. serrulatus were cut into small pieces and distilled (hydro-distillation) for $3 \mathrm{~h}$ in Clevenger-type apparatus. The process was repeated 11 times to get enough oil. The essential oil obtained was dried with anhydrous sodium 
sulfate and kept in closed vials at $4^{\circ} \mathrm{C}$ in a refrigerator (Asfaw et al., 2000). The percent yield of the obtained essential oil was calculated based on the weight of the fresh plant material $(v / w)$.

\section{Phytochemical Characterization of the Aqueous Extract}

The phenolic compounds in $T$. serrulatus aqueous extract were identified by UHPLC-DAD-ESI-MS ${ }^{\mathrm{n}}$ analysis, performed on a Ultimate 3000 (Dionex Co., Sunnyvale, CA, United States) apparatus equipped with an ultimate 3000 Diode Array Detector (Dionex Co.), and coupled to a mass spectrometer, according to the method previously described by Pereira et al. (2018). The chromatographic apparatus was composed of a quaternary pump, an autosampler, a photodiode-array detector, and an automatic thermostatic column compartment. The column used had a $100 \mathrm{~mm}$ length, $2.1 \mathrm{~mm}$ i. d., $1.9 \mu \mathrm{m}$ particle diameter, and end-capped Hypersil Gold C18 column (Thermo Scientific, Waltham, MA, United States), and its temperature was maintained at $30^{\circ} \mathrm{C}$. The solvent system used to analyze the sample include water acidified with $0.1 \%$ formic acid $(v / v)($ solvent $\mathrm{A})$ and acetonitrile (solvent $\mathrm{B})$. The elution was carried out in binary gradient by gradually increasing the amount of solvent B; from $10-20 \%$ (over $6 \mathrm{~min}$ ), from $20-25 \%$ (12 min), from $25-34 \%(30 \mathrm{~min})$ and increased up to $100 \%$ at $37 \mathrm{~min}$ maintaining for $3 \mathrm{~min}$, finally returning to the initial conditions at $40 \mathrm{~min}$. The flow rate used was $0.2 \mathrm{ml} / \mathrm{min}^{-1}$. The UV-Vis spectral data for all peaks accumulated in the range $200-600 \mathrm{~nm}$ and the chromatographic profiles were recorded at 280,320 , and $340 \mathrm{~nm}$. The mass spectrometer used was a Thermo LTQ XL (Thermo Scientific, San Jose, CA, United States) ion trap MS, equipped with an ESI source with Thermo Xcalibur Qual Browser software. The instrument was operated in negative-ion mode and the full scan covered the mass range from $\mathrm{m} / z 100$ to 2000 . Nitrogen above $99 \%$ purity was used and the gas pressure was $520 \mathrm{kPa}(75 \mathrm{psi})$. ESI needle voltage set at $5.00 \mathrm{kV}$ and an ESI capillary temperature of $275^{\circ} \mathrm{C}$. CID-MS/MS and $\mathrm{MS}^{\mathrm{n}}$ experiments were simultaneously acquired for precursor ions using helium as the collision gas with collision energy of 25-35 arbitrary units.

The major compounds in the aqueous extract were quantified using the external standard method by peak integration with the exact or structurally related compounds.

\section{Phytochemical Analysis of the Essential Oil}

The essential oil composition of $T$. serrulatus was analyzed by GC-MS according to the adapted method of Tirillini et al. (2008). For the analysis, a gas chromatograph (Agilent 7820A) equipped with a FID and a capillary column (fused silica DB-5, $30 \mathrm{~m} \times$ $0.25 \mathrm{~mm}$ i. d., $0.25 \mu \mathrm{m}$ film thickness), coupled with a mass spectrometer (Agilent 5977B) was used. $50 \mu \mathrm{L}$ of the oil was diluted in $1.5 \mathrm{ml}$ of methanol in order to improve the separation of peaks and the injection volume was $1 \mu \mathrm{L}$. The oven conditions were set initially at $60^{\circ} \mathrm{C}$ and continued for $3 \mathrm{~min}$ and then the temperature was increased at $4^{\circ} \mathrm{C} / \mathrm{min}$ to $300^{\circ} \mathrm{C}$ and held for $15 \mathrm{~min}$. The injector and detector were operated at $250^{\circ} \mathrm{C}$, the flow rate of the carrier gas (helium) was adjusted to $1 \mathrm{ml} / \mathrm{min}$ and a split ratio of 1:10 was applied. GC-MS system was operated in the EI mode at $70 \mathrm{eV}$, in the mass range from an $\mathrm{m} / z$ of 30-500 amu.

The identification of compounds was carried out by matching their mass spectra with mass spectral library of NIST (version 2.2) and the identity of each component was confirmed by comparing their retention indices (generated by Chemstation software) relative to the C6-C22 n-alkanes with those from the literature (Asfaw et al., 2000; Tirillini et al., 2008; Mancini et al., 2015). Thymol was co-eluted as a standard reference to additionally confirm its identity. The percentage composition of the components was obtained by the peak areas normalization method.

\section{Preparation of Samples for the In Vitro Experiments}

For in vitro assays, the aqueous extract was dissolved in methanol (Sigma-Aldrich ${ }^{\circledR}$, Milan, Italy) in the concentration of $0.25 \mathrm{mg} /$ $\mathrm{ml}$, after being vortexed (Vortex, Phoenix AP56, Araraquara, São Paulo, Brazil) for $5 \mathrm{~min}$ and centrifuged at $4000 \mathrm{rpm}$ at $0^{\circ} \mathrm{C}$ for $20 \mathrm{~min}$ (Eppendorf $5810 \mathrm{R}$ ) and the essential oil was diluted in the methanol in the concentration $0.33 \mathrm{mg} / \mathrm{ml}$. The stock solution concentration of quercetin was $2 \mathrm{mg} / \mathrm{ml}$.

\section{Antioxidant Activity Diphenyl-1-picrylhydrazyl Radical DPPH• Scavenging Activity}

The effect of T. serrulatus aqueous extract and essential oil against DPPH radical was determined following the method adopted by Vinholes et al. (2017). In this assay, the sample $(25 \mu \mathrm{L})$ solution (or methanol, in the case of blank) and $0.6 \mathrm{mM} \mathrm{DPPH}$ solution $(250 \mu \mathrm{L})$ were mixed in a 96-well microplate. Quercetin was used as a positive control. After shaking the microplates, the mixture was incubated in dark for $30 \mathrm{~min}$ and subsequently measured on a plate reader (Spectra Max 190) at a wavelength of $515 \mathrm{~nm}$. The results were calculated as inhibition percentage (\%I).

\section{Hydroxyl Radical ('OH) Scavenging Activity}

The ability of the samples to scavenge the hydroxyl radical was determined according to the method described by Vinholes et al. (2017) with adaptations. Each test sample $(25 \mu \mathrm{L})$ was reacted by mixing with $110 \mu \mathrm{L}$ of iron sulfate heptahydrate solution $(8 \mathrm{mM}$, prepared in EDTA-Na $20 \mu \mathrm{M}$ ), $50 \mu \mathrm{L}$ of hydrogen peroxide solution $(7 \mathrm{mM})$ and $74 \mu \mathrm{L}$ of salicylic acid solution $(3 \mathrm{mM})$. Quercetin was used as positive control. After shaking, the microplates were incubated at $37^{\circ} \mathrm{C}$ for $30 \mathrm{~min}$ and the absorbance was read at $515 \mathrm{~nm}$. The results were expressed as inhibition percentage (\% I).

\section{Nitric Oxide Radical ('NO) Scavenging Activity}

The nitric oxide radical scavenging ability of the T. serrulatus aqueous extract and essential oil was determined according to the method described by Vinholes et al. (2011). The samples $(50 \mu \mathrm{L})$ and sodium nitroprusside $(50 \mu \mathrm{L}, 20 \mathrm{mM})$ were added to a $96-$ well plate and incubated under the effect of light for $60 \mathrm{~min}$ at room temperature. Subsequently, $2 \%$ phosphoric acid solution 
$(50 \mu \mathrm{L})$ and Griess reagent $(50 \mu \mathrm{L})$ were added to the mixture and further incubated for $10 \mathrm{~min}$ at room temperature in the dark and the absorbance was measured on a micro plate reader (Spectra Max 190), at a wavelength of $562 \mathrm{~nm}$. Quercetin was used as standard. The results were calculated as inhibition percentage (\%I).

\section{In Vitro Blood Glucose Lowering Effect Inhibition of $\alpha$-Amylase Activity}

The activity of $T$. serrulatus aqueous extract and essential oil against the $a$-amylase enzyme was assessed using the procedure described by Satoh et al. (2015) with some adaptations. Each extract $(15 \mu \mathrm{L})$ was mixed with phosphate buffer $(50 \mu \mathrm{L}, \mathrm{pH} 7.0)$ and the $\alpha$-amylase enzyme $\left(12.5 \mu \mathrm{L}, 241.71 \mathrm{U} 62 \mathrm{ml}^{-1}\right)$, followed by incubation at $37^{\circ} \mathrm{C}$ for $5 \mathrm{~min}$. The soluble starch as a substrate $(62.5 \mu \mathrm{L})$ was added to initiate the reaction, and further incubated at $37^{\circ} \mathrm{C}$ for $15 \mathrm{~min}$. The reaction was stopped by adding $1 \mathrm{M}$ hydrochloric acid $(12.5 \mu \mathrm{L})$ to the reaction mixture. Twentyfive $\mu \mathrm{L}$ of the iodine solution $(25 \mu \mathrm{L}, 0.005 \mathrm{M})$ and potassium iodide $(0.005 \mathrm{M})$ was added for color formation. Acarbose was used as a positive control. The absorbance reading was done on polystyrene microplates containing 96 wells (Spectra Max 190Molecular Devices) at a wavelength of $690 \mathrm{~nm}$. The $\alpha$-amylase enzyme inhibitory activity of the samples was expressed as $\mathrm{IC}_{50}$ $(\mathrm{mg} / \mathrm{ml})$.

\section{Inhibition of $\alpha$-Glucosidase Activity}

The inhibition of the a-glucosidase enzyme was determined according to the method described by Vinholes et al. (2011), with some adaptations. The enzymatic samples $(10 \mu \mathrm{L})$ were added in $p$-nitrophenyl-a-D-glycopyranosidium substrate $(50 \mu \mathrm{L}$, $3.25 \mathrm{mM}$ ) (diluted in $\mathrm{pH} 7.0$ phosphate buffer) solution. The enzyme $\left(50 \mu \mathrm{L}, 9.37 \mathrm{U} \mathrm{mL}^{-1}\right.$ diluted in phosphate buffer, $\mathrm{pH}$ 7.0) was then added in the mixture to start the reaction followed by incubation of the mixture at $37^{\circ} \mathrm{C}$ for $10 \mathrm{~min}$. Acarbose was used as a positive control. The absorbance reading was done on polystyrene microplates containing 96 wells in a Spectra Max-Molecular Devices plate reader and was read at a wavelength of $405 \mathrm{~nm}$, immediately after the end of the reaction. The results of inhibitory activity of $\alpha$-glucosidase enzyme were expressed as $\mathrm{IC}_{50}$.

\section{In Vivo Blood Glucose Lowering Effect Preparation of Animals}

In this study, healthy albino mice (20-30 g), after random selection, were housed in animal cages each containing groups of six mice with natural night-daytime (12-h light/dark cycle) exposure and at room temperature. The mice were provided standard pellets and tap water ad libitum. During the experiments, the mice were fasted overnight (12-14 h) but allowed free access to tap water. The in vivo study was approved by the Health Research Ethics Review Committee (ERC1550/2018), College of Health Sciences, Mekelle University and all the procedures involving animals were conducted to the internationally accepted guidelines.

\section{Acute Oral Toxicity Test}

Acute oral toxicity was performed according to OECD (Organization for Economic Co-operation and Development) guidelines 425. Albino mice of female sex selected by random sampling were fasted for 3-4 h prior to dosing with free access to water. First, $2000 \mathrm{mg} / \mathrm{kg}$ dose, dissolved in $2 \%$ tween 80 , was administered orally to a single mouse for each of the test samples. The mice were then observed for physical or behavioral changes for $24 \mathrm{~h}$ with special attention during the first $4 \mathrm{~h}$. Mice were given access to food after $2 \mathrm{~h}$ of dosing. After survival of the administered mice for $24 \mathrm{~h}$, four additional mice (for each sample) were administered the same amount of the aqueous extract/essential oil under the same conditions. For any possible toxic effect of the sample, the mice were closely observed in the first $4 \mathrm{~h}$ and then at regular intervals up to 14 days.

\section{Hypoglycemic Effect on Normoglycemic Mice}

In this method, overnight fasted mice of both sexes with normal blood glucose levels (BGL) were divided into eight groups $(n=6)$. The positive control group received standard antidiabetic drug (glibenclamide $10 \mathrm{mg} / \mathrm{kg}$ ), while the negative control group received the vehicle [2\% tween $80(10 \mathrm{ml} / \mathrm{kg})]$, and the test groups were administered with the aqueous extract of $150 \mathrm{mg} / \mathrm{kg}, 300 \mathrm{mg} / \mathrm{kg}$, and $600 \mathrm{mg} / \mathrm{kg}$; and essential oil of $150 \mathrm{mg} / \mathrm{kg}, 300 \mathrm{mg} / \mathrm{kg}$, and $600 \mathrm{mg} / \mathrm{kg}$ of T. serrulatus as per body weight of the mice.

To assess the hypoglycemic effect of the test substances, whole blood samples from the control and test groups of mice were drawn immediately before $(0 \mathrm{~h})$ and after 1,3 , and $6 \mathrm{~h}$ following administration of standard drug and test samples, by tail snip method. BGL was measured using a glucometer. Blood samples were taken at least three times and average value was determined. The hypoglycemic effects of the test samples were compared with the BGLs of the control groups (Sah et al., 2011).

\section{Oral Glucose Tolerance Test in Normoglycemic Mice}

The oral glucose tolerance test was performed according to the procedure described by Lanjhiyana et al. (2011). Overnight fasted mice were divided into nine groups of six mice in each group $(n=6)$. Group 1 received $10 \mathrm{ml} / \mathrm{kg}$ of $2 \%$ tween 80 and served as a normal control group and Group 2 received $2 \mathrm{~g} / \mathrm{kg}$ of glucose (negative control). Groups 3, 4, and 5 received aqueous extract of $T$. serrulatus at doses of 150, 300, and $600 \mathrm{mg} / \mathrm{kg}$ body weight, and groups 6, 7, and 8 were given essential oil at doses of 150,300 , and $600 \mathrm{mg} / \mathrm{kg}$ body weight. Group 9 received glibenclamide, $10 \mathrm{mg} / \mathrm{kg}$, and served as a positive control group. Thereafter, a glucose load $(2 \mathrm{~g} / \mathrm{kg}$ body weight) was given to each mouse, except the normal control group, exactly after $30 \mathrm{~min}$ post administration of the test samples, standard drug, or vehicle.

Blood glucose profile of each mouse was measured at five time points: immediately prior to dosing $(0 \mathrm{~min}), 30,60,90$, and $120 \mathrm{~min}$ after administration of glucose in order to determine their BGLs. Blood samples from each mouse were drawn from tail vein, using tail snip method, three to four times and the average blood glucose values were taken. The BGLs were measured using a glucometer. The area under the blood glucose concentration curve (AUC) of each group was determined by plotting BGL 


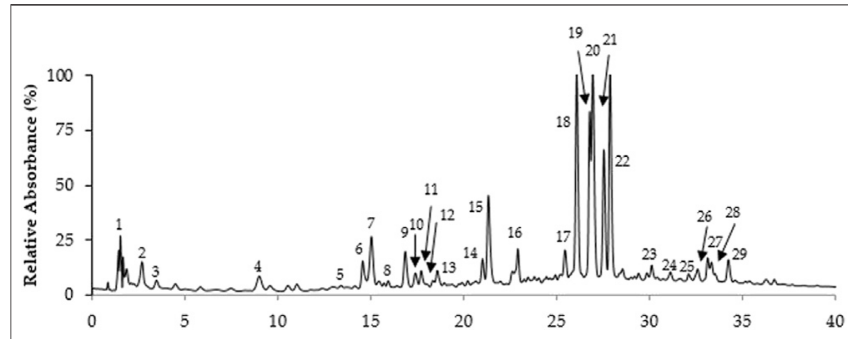

FIGURE 1 | LC-MS Chromatographic profile of $T$. serrulatus aqueous extract.

against a time graph, and it was used to evaluate the overall percentage reduction in post glucose load hyperglycemia.

\section{Antihyperglycemic Activity on Streptozotocin Induced Diabetic Mice}

Hyperglycemia was induced in overnight fasted mice by injecting streptozotocin (STZ) $(55 \mathrm{mg} / \mathrm{kg}$ in $0.1 \mathrm{M}$ citrate buffer, $\mathrm{pH} 4.5$ ) intraperitoneally a single time (Srinivasan and Ramarao, 2007). The changes in BGL and body weight were noted regularly. After three days, mice with fasting blood glucose (FBG) greater than $200 \mathrm{mg} / \mathrm{dl}$ were considered diabetic and were used for the antihyperglycemic study.

The antihyperglycemic activity of $T$. serrulatus aqueous extract and essential oil was performed according to the method described by Kabbaoui et al. (2016). The mice were equally divided and randomly assigned into nine groups of six mice $(n=6)$ each: Group 1: healthy mice received the vehicle $(2 \%$ tween $80,10 \mathrm{ml} / \mathrm{kg}$ ) and served as normal control group. Group 2: diabetic mice received a daily oral dose of $2 \%$ tween 80 $(10 \mathrm{ml} / \mathrm{kg})$, served as diabetic control group. Groups 3, 4, and 5: diabetic mice received a daily oral dose of 150,300 , and $600 \mathrm{mg} / \mathrm{kg}$ aqueous extract, respectively. Groups 6, 7, and 8: diabetic mice received a daily oral dose of 150,300 , and $600 \mathrm{mg} / \mathrm{kg}$ of the essential oil respectively. Group 9: diabetic mice received a daily oral dose of $10 \mathrm{mg} / \mathrm{kg}$ of the standard drug glibenclamide and served as a positive control group. The test samples, standard drug, and vehicle were started 3 days after induction of diabetes and administered orally on a once daily basis for 21 days using oral gavage.

Antihyperglycemic effect and body weight change were evaluated by estimating the FBG levels and weight on days 0 , 7,14 , and 21 .

\section{STATISTICAL ANALYSIS}

The results in this study are expressed as mean \pm SEM. The in vitro antioxidant and blood glucose lowering values were computed using Graph Pad Prism version 8 for Windows. The in vivo data were analyzed using SPSS version 25 by means of ANOVA to differentiate between means of all parameters and the source of significant differences was determined by applying Tukey's post-hoc tests with multiple comparisons.
The results were considered significant $\left(^{*}\right)$ when $p$-value was less than 0.05 .

\section{RESULTS}

\section{Phenolic Profile of the Aqueous Extract}

The extraction yield of T. serrulatus aqueous extract was $11.4 \%$ (2.28 g). Overall, its LC-MS analysis allowed the identification of distinct phenolic compounds, being this particularly rich in caffeic acid derivatives and salvianolic acids (Figure $\mathbf{1}$ and Table 1). Among them, the two compounds eluted in peaks 19 and 22 were assigned to two isomers of salvianolic acid $\mathrm{K}$, as they exhibited the main $[\mathrm{M}-\mathrm{H}]^{-}$ion at $m / z 555$ in MS spectrum and the major product ions at $m / z$ at 493 and 359 in $\mathrm{MS}^{2}$ analysis. Notably, these isomers represented almost half $(90 \mathrm{mg} / \mathrm{g}$ of the extract) of the total quantified phenolic compounds (194.1 \pm $15.9 \mathrm{mg} / \mathrm{g}$ of the extract). In addition, salvianolic acid $\mathrm{B}\left(\mathrm{T}_{\mathrm{R}}\right.$ $27.6 \mathrm{~min}, \mathrm{MW} 718)$, the derivative of salvianolic acid $\mathrm{F}\left(\mathrm{T}_{\mathrm{R}} 15.0\right.$ and $16.9 \mathrm{~min}, \mathrm{MW} 376)$ and salvianolic acid $\mathrm{A}\left(\mathrm{T}_{\mathrm{R}} 34.3 \mathrm{~min}, \mathrm{MW}\right.$ 494), appeared in moderate amounts. In detail, salvianolic acid $B$ $\left(\mathrm{UV}_{\max }\right.$ at 287 and $\left.330 \mathrm{~nm}\right)$ presented $\mathrm{m} / z$ at 717 and the fragmentation pattern with successive losses of $198 \mathrm{u}$ (danshensu) or $180 \mathrm{u}$ (caffeic acid) units. Salvianolic acid A produced a base peak at $\mathrm{m} / z 295$ by the loss of $198 \mathrm{u}$ (danshesu) and other ions characteristics to this salvianolic acid fragmentation.

Rosmarinic acid (MW 360), a well-known dimer of caffeic acid characteristic from Thymus plants, and its derivatives overall represented about $15 \%$ of the total phenolics. This compound was eluted in peak 18, which showed the [M$\mathrm{H}]^{-}$ion at $m / z 359$ and the product ions at $m / z 161,179$, 197, 223 in MS $^{2}$. Also, two other rosmarinic acid derivatives were found in moderate amounts in the extract. These were eluted in peaks 16 and 17 , being characterized by $[\mathrm{M}-\mathrm{H}]^{-}$ions at $m / z 521$ and 403 , respectively, and the presence of a major product ion at $m / z 359$.

Flavones, namely, isoscutellarein, luteolin, and apigenin glycosides were also representative phenolic constituents of the extract, accounting for $16 \%, 10 \%$ and $3 \%$ of the total phenolic content of the extract, respectively. Among these, isoscutellarein$O$-glucuronide $\left(\mathrm{T}_{\mathrm{R}} 27.0 \mathrm{~min}\right.$ ) was assigned due the $\mathrm{UV}_{\max }$ at 268 and $337 \mathrm{~nm}$ and the $\mathrm{m} / z 461 \rightarrow 285$ consistent with the loss of a glucuronyl moiety $(-176 \mathrm{u})$. In a similar way, the fragment ion at $\mathrm{m} / z 285$ and the $\mathrm{UV}_{\max }$ at 254, 264 and $345 \mathrm{~nm}$, compatible with luteolin, and the main ion $[\mathrm{M}-\mathrm{H}]^{-}$at $\mathrm{m} / z, 461$ allowed the identification of luteolin-O-glucuronide $\left(\mathrm{T}_{\mathrm{R}} 21.3 \mathrm{~min}, \mathrm{MW}\right.$ 462), eluted in peak 15. Peak 6 with $\mathrm{UV}_{\max }$ compatible with apigenin $(271,333 \mathrm{~nm})$ showed a molecular ion at $m / z 593$ and typical $C$-glycosyl fragments at $m / z 473,503$ and 383, allowing the identification of apigenin di- $C$-glucoside.

\section{Chemical Composition of the Essential Oil}

The fresh erial parts of $T$. serrulatus after hydro-distillation yielded $0.9 \%$ (24.75 ml) of essential oil, which was characterized by a pale yellowish and a spicy odor. GC-MS analysis of the essential oil revealed 22 components, representing about $99.92 \%$ 
TABLE 1 | Phenolic compounds of T. serrulatus aqueous extracts determined by UHPLC-DAD-ESI-MS ${ }^{n}$

\begin{tabular}{|c|c|c|c|c|c|c|}
\hline NP & $\mathbf{T}_{\mathrm{R}}(\mathrm{min})$ & $\lambda \operatorname{Max}(\mathrm{nm})$ & [H-M]- & $\begin{array}{l}\text { MS/MS fragments } \\
\qquad(\mathrm{m} / \mathrm{z})\end{array}$ & Probable compound & $\begin{array}{c}\text { Phenolic content } \\
\text { (mg/g)/\% composition }\end{array}$ \\
\hline 1 & 1.7 & 206 & 191 & 111,173 & Quinic acid & $\mathrm{D}$ \\
\hline 2 & 3.5 & 280 & 197 & $179,73,153$ & Danshensu & $6.4 \pm 0.9 / 3.3$ \\
\hline 3 & 3.7 & 279 & 571 & $509,553,237$ & Yunnaneic acid $\mathrm{E}$ & $1.7 \pm 0.4 / 0.88$ \\
\hline 4 & 9.0 & 292,324 & 367 & $193,191,173$ & Feruloylquinic acid & $1.3 \pm 0.1 / 0.67$ \\
\hline 5 & 13.4 & 284 & 387 & 207, 163, 369 & HydroxyJasm acid-O-hexoside & $\mathrm{D}$ \\
\hline 6 & 14.6 & 271,333 & 593 & $473,503,353,383,575$ & Apigenin di-C-glucoside & $5.3 \pm 0.4 / 2.73$ \\
\hline 7 & 15.0 & 290, 324sh & 375 & $313,269,179,135$ & Salvianolic acid F derivative & $12.2 \pm 1.7 / 6.29$ \\
\hline 8 & 16.0 & 283 & 449 & 287 & Eriodictyol-O-hexoside & $0.4 \pm 0.1 / 0.21$ \\
\hline 9 & 16.9 & 287, 318sh & 375 & $313,269,179,135$ & Salvianolic acid F derivative & $8.4 \pm 0.7 / 4.33$ \\
\hline 10 & 17.4 & 282,341 & 477 & $301,299,277,191$ & Quercetin glucuronide & $1.9 \pm 0.2 / 0.98$ \\
\hline 11 & 17.7 & 281,341 & 463 & 301 & Quercetin-O-hexoside & $2.1 \pm 0.3 / 1.08$ \\
\hline 12 & 18.4 & 287,329 & 553 & 491, 357, 399, 535 & Salvianolic acid $\mathrm{C}$ derivative & $\mathrm{D}$ \\
\hline 13 & 18.6 & 242, 260sh, 341 & 447 & 285 & Luteolin-7-O-glucoside & $2.5 \pm 0.3 / 1.29$ \\
\hline 14 & 21.1 & 254,267 sh, 341 & 593 & 285 & Luteolin-O-diglucoside & $1.4 \pm 0.2 / 0.72$ \\
\hline 15 & 21.3 & $254,264 s h, 345$ & 461 & 285 & Luteolin-O-glucuronide & $17.3 \pm 1.5 / 8.91$ \\
\hline 16 & 23.0 & 292sh, 308 & 521 & $359,179,197,161$ & Rosmarinic acid hexoside & $2.9 \pm 0.2 / 1.49$ \\
\hline 17 & 25.5 & 287sh, 318 & 403 & $367,385,359,313,223$ & Rosmarinic acid derivative & $2.1 \pm 0.3 / 1.08$ \\
\hline 18 & 26.1 & 290sh, 328 & 359 & $161,179,197,223,133,123$ & Rosmarinic acid & $19.4 \pm 1.5 / 9.99$ \\
\hline 19 & 26.9 & $287,326 s h$ & 555 & $493,359,401,537$ & Salvianolic acid K (isomer 1) & $53.8 \pm 2.9 / 27.72$ \\
\hline 20 & 27.0 & 268,337 & 461 & 285 & Isoscutellarein-O-glucuronide & $31.3 \pm 3.3 / 16.13$ \\
\hline 21 & 27.6 & 287, 330sh & 717 & $519,357,555,475$ & Salvianolic acid B & $22.7 \pm 1.8 / 11.7$ \\
\hline 22 & 27.9 & 287, 332sh & 555 & 493, 359, 195, 179 & Salvianolic acid K (isomer 2) & $37.1 \pm 2.7 / 19.11$ \\
\hline 23 & 30.1 & $252,266,344$ & 591 & $531,549,285$ & Luteolin acetyl dipentoside & $1.5 \pm 0.2 / 0.77$ \\
\hline 24 & 31.1 & 287sh, 326 & 373 & $179,161,135,197,329,355$ & Methyl rosmarinate & $1.3 \pm 0.1 / 0.67$ \\
\hline 25 & 32.1 & 284 sh, 340 & 537 & $493,515,519,357,297,179$ & Caffeoyl RA (isomer1) & $\mathrm{D}$ \\
\hline 26 & 32.6 & 287sh, 326 & 537 & $493,515,359,375,357$ & Caffeoyl RA (isomer2) & $1.4 \pm 0.1 / 0.72$ \\
\hline 27 & 33.1 & 284sh, 341 & 537 & $493,519,515,357,339,179$ & Caffeoyl RA (isomer3) & $\mathrm{D}$ \\
\hline 28 & 33.4 & 287sh, 328 & 537 & $493,519,357,438,339,197$ & Caffeoyl RA (isomer4) & $\mathrm{D}$ \\
\hline 29 & 34.3 & 287, 332sh & 493 & $359,357,313,161,295$ & Salvianolic acid A & $4.7 \pm 0.5 / 2.42$ \\
\hline \multicolumn{6}{|c|}{ Total quantified phenolic content (mg/g) } & $194.1 \pm 15.9$ \\
\hline
\end{tabular}

Values expressed as mg/g of extract; NP, Number of peak; $D$, Detected; $T_{R}$, Retention time; RA, Rosmarinic acid, sh, shoulder.

of the total detected constituents. The essential oil was mostly composed of thymol (56.24\%), carvacrol (15.44\%), p-cymene (9.39\%), $\gamma$-terpinene (9.34\%), carvacrol methyl ether (2.77\%), and $\beta$-myrcene $(2.26 \%)$. Other components were present in amounts less than 2\% (Figure 2).

The composition of the essential oil is summarized in Table 2. For easier comparison and speculating the intended activities of the oil, the components were categorized into five classes of phytochemicals, which were monoterpene hydrocarbons, oxygenated monoterpenes, sesquiterpene hydrocarbons, phenolic compounds, and other components. Accordingly, the essential oil of $T$. serrulatus was mainly composed of phenolic monoterpenes $(71.68 \%)$ followed by monoterpene hydrocarbons (23.25\%).

\section{In Vitro Antioxidant Activity}

The antioxidant potential of the essential oil and aqueous extract were determined on the basis of their scavenging activity of the free radicals, namely against $\mathrm{DPPH}^{\bullet},{ }^{\circ} \mathrm{OH}$ and ${ }^{\circ} \mathrm{NO}$. As presented in Table 3, the essential oil and the aqueous extract were both able to eliminate the $\mathrm{DPPH}$ and $\mathrm{OH}$ radicals, with higher percentages of inhibition for the $\mathrm{DPPH}^{\circ}$. Curiously, essential oil was able to partially scavenge ${ }^{\circ} \mathrm{NO}$ (approximately $35 \%$ ), while no such ability was registered for the aqueous extract and quercetin.

\section{In Vitro Blood Glucose Lowering Effect}

The essential oil was also more potent than the aqueous extract in regard to the ability to inhibit $\alpha$-amylase and $\alpha$-glycosidase enzymes. Also, both the aqueous extract and essential oil were more effective than the drug acarbose against the enzyme a-glycosidase. Moreover, the essential oil was five times more potent than acarbose against the enzyme $\alpha$-amylase (Table 4).

\section{In Vivo Blood Glucose Lowering Effect Acute Toxicity Effect}

The results of the acute oral toxicity indicated no mortality during the 14 days follow-up. The findings suggested that both the aqueous extract and essential oil are safe as no observable adverse effects were found at the maximum dose $2000 \mathrm{mg} / \mathrm{kg}$ body weight.

\section{Hypoglycemic Effect}

The effects of aqueous extract and essential oil of T. serrulatus on FBG level in normoglycemic mice is shown in Table 5. At the lowest dose $(150 \mathrm{mg} / \mathrm{kg})$, no significant decrease in blood glucose level was observed in both tested samples. Unlike the essential oil, which did not show any hypoglycemic property at all dose levels, the aqueous extract (at $600 \mathrm{mg} / \mathrm{kg}$ ) showed statistically 


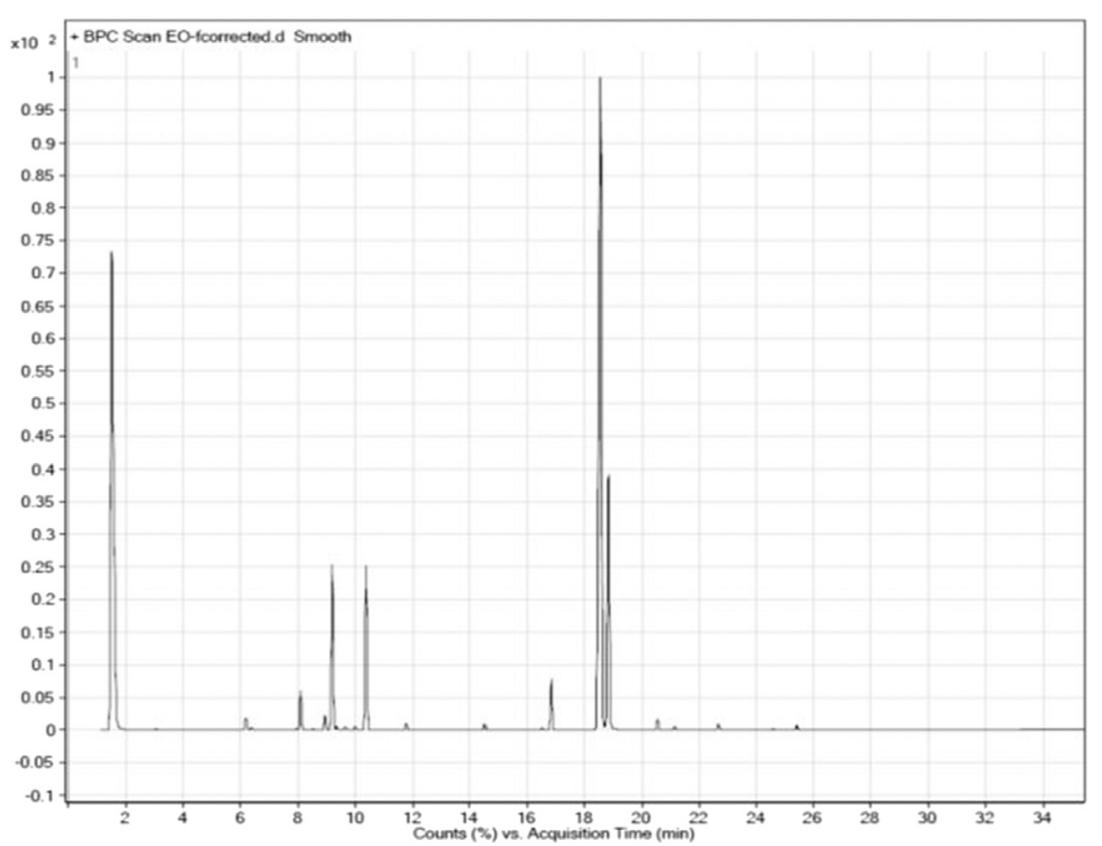

FIGURE 2 | GC-MS chromatographic profile of the essential oil of $T$. serrulatus.

significant $(p<0.01)$ reduction in blood glucose level starting from the $3 \mathrm{rd} h$ of administration as compared to the negative control. After $6 \mathrm{~h}$ of administration, a statistically significant $(p<0.001)$ reduction in blood glucose level was observed at $300 \mathrm{mg} / \mathrm{kg}$ of the aqueous extract. Moreover, the effect of $300 \mathrm{mg} / \mathrm{kg}$ aqueous extract $(22.53 \%)$ was comparable with the effect of the standard antidiabetic drug glibenclamide $(22.82 \%)$ in reducing the blood glucose level. Also, a statistically significant $(p<0.001)$ decrease in the blood glucose level of the positive control group was observed after $1 \mathrm{~h}$ of the glibenclamide's administration.

\section{Oral Glucose Tolerance Test}

The essential oil and water extract both showed statistically significant $(p<0.001)$ suppression on BGL at all dose levels starting from $30 \mathrm{~min}$ of administration of glucose as compared to the negative control group administered with the vehicle $(2 \%$ tween $80,10 \mathrm{ml} / \mathrm{kg}$ ). Except for the normal control, the remaining groups of mice exhibited a peak BGL 30 min after glucose load, which was followed by a decrease over time to the pre-prandial level (Figure 3).

The AUCs of glucose concentration in groups treated with $T$. serrulatus aqueous extract, essential oil, and glibenclamide, were significantly reduced by $36.99 \% \quad(600 \mathrm{mg} / \mathrm{kg}), \quad 47.19 \%$ $(300 \mathrm{mg} / \mathrm{kg})$ and $60.45 \%(10 \mathrm{mg} / \mathrm{kg})$ respectively, as compared to the negative control group. The essential oil of $T$. serrulatus at all dose levels produced plasma glucose levels significantly lower than those of the aqueous extract at 30,60, and 120 min after the glucose administration in which the AUC during the OGTT was significantly decreased by $41.35 \%, 47.19 \%$, and $46.51 \%$ at 150 , 300 , and $600 \mathrm{mg} / \mathrm{kg}$ dose levels, respectively.

\section{Antihyperglycemic Activity on Streptozotocin-Induced Diabetic Mice}

In the three-week treatment course, the fasting blood glucose level of the mice were measured once a week as shown in Table 6. There was no significant difference observed in the fasting blood glucose level between the standard and test groups before initiating the treatment. At the dose of $600 \mathrm{mg} / \mathrm{kg}$, the groups that received standard drug and the test substances showed statistically significant variations in their FBG levels within the first week of treatment $(p<0.01$ and $p<0.001$, for the aqueous extract and essential oil respectively). Furthermore, at the end of the second week, the test groups that received $600 \mathrm{mg} / \mathrm{kg}$ of both aqueous extract and essential oil $(p<0.001)$ and $300 \mathrm{mg} / \mathrm{kg}$ of the essential oil $(p<0.05)$ showed significantly different FBG levels at the end of the second week. On day 21, the test groups that received $150 \mathrm{mg} / \mathrm{kg}(p<0.05)$ and $300 \mathrm{mg} / \mathrm{kg}$ $(p<0.001)$ of the aqueous extract also showed a statistically significant reduction in their FBG levels.

The aqueous extract and essential oil at the highest dose level $(600 \mathrm{mg} / \mathrm{kg})$ exerted maximum antihyperglycemic activity (44.14\%) and $30.82 \%$ respectively. The extract and essential oil revealed a dose and time dependent antihyperglycemic effect.

\section{Effect on Body Weight Changes}

In this study, the STZ-induced untreated diabetic group showed $19.97 \%$ loss in body weight and the normal control group showed a $4.96 \%$ increase during the treatment period. In addition to the diabetic group, the group of mice treated with $150 \mathrm{mg} / \mathrm{kg}$ of both of the test substances produced substantial reductions in their body weight as compared to the normal mice. The 
TABLE 2 | Chemical composition of the essential oil extracted from the aerial parts of $T$. serrulatus.

\begin{tabular}{|c|c|c|c|c|c|}
\hline Peak № & Compound name & $\mathbf{T}_{\mathrm{R}}$ (min.) & $\mathbf{R i}$ & $\%$ Area & Identification \\
\hline 1 & $a$-Thujene & 6.176 & 931 & 0.75 & 1.2 \\
\hline 2 & $a$-Pinene & 6.374 & 937 & 0.14 & 1.2 \\
\hline 3 & 3-Octanone & 7.945 & 986 & 0.07 & 1.2 \\
\hline 4 & $\beta$-Myrcene & 8.092 & 991 & 2.26 & 1.2 \\
\hline 5 & a-Phellandrene & 8.531 & 1003 & 0.09 & 1.2 \\
\hline 6 & a-Terpinene & 8.929 & 1017 & 0.83 & 1.2 \\
\hline 7 & p-Cymene & 9.201 & 1022 & 9.39 & 1.2 \\
\hline 8 & D-sylvestrene & 9.348 & 1027 & 0.15 & 1.2 \\
\hline 9 & $(Z)$ - $\beta$-ocimene & 9.652 & 1038 & 0.14 & 1.2 \\
\hline 10 & $(E)$ - $\beta$-ocimene & 9.997 & 1049 & 0.17 & 1.2 \\
\hline 11 & $\gamma$-Terpenene & 10.384 & 1060 & 9.34 & 1.2 \\
\hline 12 & Linalool & 11.787 & 1099 & 0.35 & 1.2 \\
\hline 13 & Terpinen-4-ol & 14.520 & 1177 & 0.33 & 1.2 \\
\hline 14 & Thymol methyl ether & 16.520 & 1235 & 0.11 & 1.2 \\
\hline 15 & Carvacrol methyl ether & 16.844 & 1244 & 2.77 & 1.2 \\
\hline 16 & Thymol & 18.572 & 1291 & 56.24 & $1,2,3$ \\
\hline 17 & Carvacrol & 18.855 & 1299 & 15.44 & 1.2 \\
\hline 18 & Thymol acetate & 20.540 & 1355 & 0.58 & 1.2 \\
\hline 19 & Carvacrol acetate & 21.147 & 1371 & 0.20 & 1.2 \\
\hline 20 & (E)-caryophyllene & 22.674 & 1419 & 0.31 & 1.2 \\
\hline 21 & Germacrene D & 24.592 & 1481 & 0.07 & 1.2 \\
\hline \multirow[t]{7}{*}{22} & $\beta$-Bisabolene & 25.409 & 1509 & 0.26 & 1.2 \\
\hline & \multicolumn{2}{|c|}{ Total quantified components } & \multicolumn{2}{|c|}{$99.92 \%$} & \\
\hline & \multicolumn{2}{|c|}{ Monoterpene hydrocarbons } & \multicolumn{2}{|c|}{23.21} & \\
\hline & \multicolumn{2}{|c|}{ Oxygenated monoterpenes } & \multicolumn{2}{|c|}{4.32} & \\
\hline & \multicolumn{2}{|c|}{ Sesquiterpene hydrocarbons } & \multicolumn{2}{|c|}{0.64} & \\
\hline & \multicolumn{2}{|c|}{ Phenolic compounds } & & & \\
\hline & Others & & & & \\
\hline
\end{tabular}

Identification method: 1, comparison of the Kovats retention indices with published data; 2, comparison of mass spectra with those listed in the NIST 2.2; 3, co-injection with authentic compound.

TABLE 3 | Antioxidant activity of Thymus serrulatus aqueous extract and essential oil.

\begin{tabular}{|c|c|c|c|}
\hline \multirow[t]{2}{*}{ Sample } & \multirow[b]{2}{*}{$\bullet$ DPPH } & \multicolumn{2}{|c|}{ Radical capture (\%) } \\
\hline & & $\bullet \mathrm{OH}$ & $\bullet N O$ \\
\hline TSEO & $94.51 \pm 0.08$ & $51.35 \pm 0.59$ & $34.89 \pm 11.88$ \\
\hline TSAE & $93.60 \pm 0.03$ & $48.89 \pm 1.29$ & ND \\
\hline Quercetin & $92.98 \pm 0.38$ & ND & ND \\
\hline
\end{tabular}

Results expressed as the mean of $\%$ inhibition \pm standard deviation. TSEO, Thymus serrulatus essential oil; TSAE, Thymus serrulatus aqueous extract; ${ }^{\bullet} \mathrm{OH}$, hydroxyl radical;

'NO, nitric oxide radical; ${ }^{\circ} \mathrm{DPPH}, 2,2-$ diphenyl-1-picrylhydrazyl radical; ND, not detected.

body weight of diabetic mice receiving glibenclamide and those treated with $600 \mathrm{mg} / \mathrm{kg}$ of the aqueous extract and essential oil of $T$. serrulatus showed no significant reduction over the experimental time. A dose dependent improvement in the body weight parameter of mice was observed during the experiment (Table 7).

\section{DISCUSSION}

As the pharmacological activities of different plant extracts are closely associated to their bioactive compounds, the chemical
TABLE 4 | Inhibitory ability ( $\left(\mathrm{C}_{50}, \mathrm{mg} / \mathrm{mL}\right)$ of Thymus serrulatus aqueous extract and essential oil against the digestive enzymes $\alpha$-glucosidase and $\alpha$-amylase.

\begin{tabular}{lcc}
\hline \multirow{2}{*}{ Sample } & \multicolumn{2}{c}{$\mathbf{I C}_{\mathbf{5 0}}$ value $(\mathbf{m g} / \mathbf{m l})$} \\
\cline { 2 - 3 } & $\boldsymbol{\alpha}$-amylase & $\boldsymbol{\alpha}$-glucosidase \\
\hline TSEO & $0.01 \pm 0.00$ & $0.11 \pm 0.01$ \\
TSAE & $24.47 \pm 0.29$ & $2.47 \pm 0.45$ \\
Acarbose & $0.05 \pm 0.02$ & $16.88 \pm 10.69$
\end{tabular}

Results expressed as mean \pm standard deviation. TSEO, Thymus serrulatus essential oil; TSAE, Thymus serrulatus aqueous extract.

compositions of the aqueous extract and essential oil of $T$. serrulatus were determined. The aqueous extract of $T$. serrulatus was shown to be rich in caffeic acid derivatives (e.g., rosmarinic acid) and salvianolic acids, the latter formed by danshensu linked to caffeic acid moieties (Ma et al., 2019). This finding is in agreement with aqueous decoction of $T$. carnosus in which salvianolic acid $\mathrm{K}(19.7 \mathrm{mg} / \mathrm{g}$ from $42.92 \mathrm{mg} / \mathrm{g}$ total phenolics) and salvanolic acid A isomers $(16.91 \mathrm{mg} / \mathrm{g})$ constituted the major phenolic content (MartinsGomes et al., 2018). Even though it is known that Thymus species are rich in rosmarinic acid (Pereira and Cardoso, 2013; Afonso et al., 2017), this was clearly less representative (15\%) in $T$. serrulatus aqueous extract. These differences in phytochemical contents can depend considerably on extrinsic and intrinsic 
TABLE 5 | Hypoglycemic effects of the aqueous extract and essential oil of $T$. serrulatus in normoglycemic mice.

Treatment groups

1 (negative control)
2 (TSAE $150 \mathrm{mg} / \mathrm{kg})$
3 (TSAE $300 \mathrm{mg} / \mathrm{kg})$
4 (TSAE $600 \mathrm{mg} / \mathrm{kg})$
5 (TSEO $150 \mathrm{mg} / \mathrm{kg})$
$6($ TSEO $300 \mathrm{mg} / \mathrm{kg})$
7 (TSEO $600 \mathrm{mg} / \mathrm{kg})$
8 (GB $10 \mathrm{mg} / \mathrm{kg})$

Fasting blood glucose concentration $(\mathrm{mg} / \mathrm{dl})$

\begin{tabular}{|c|c|c|c|c|}
\hline \multicolumn{4}{|c|}{ Fasting blood glucose concentration (mg/dl) } & \multirow{2}{*}{$\begin{array}{c}\% \text { Change in FBC } \\
\text { (hr. 0-6) }\end{array}$} \\
\hline $\mathbf{O h}$ & $1 \mathrm{~h}$ & $3 \mathbf{h}$ & $6 \mathrm{~h}$ & \\
\hline $85.67 \pm 0.80$ & $81.17 \pm 0.79$ & $75.00 \pm 1.13$ & $73.33 \pm 0.95$ & $-14.40 \%$ \\
\hline $85.50 \pm 1.20$ & $79.67 \pm 0.95$ & $70.33 \pm 2.40$ & $77.67 \pm 0.92$ & $-9.16 \%$ \\
\hline $84.33 \pm 1.23$ & $84.17 \pm 2.52$ & $71.33 \pm 2.29$ & $65.33 \pm 2.32^{\star \star \star}$ & $-22.53 \%$ \\
\hline $76.17 \pm 0.87$ & $78.00 \pm 0.89$ & $67.83 \pm 0.60^{*}$ & $66.67 \pm 0.88^{\star \star}$ & $-12.46 \%$ \\
\hline $75.83 \pm 0.31$ & $82.17 \pm 0.48$ & $77.00 \pm 0.37$ & $81.00 \pm 0.63$ & $+6.82 \%$ \\
\hline $83.83 \pm 0.48$ & $84.00 \pm 0.45$ & $76.17 \pm 0.95$ & $79.33 \pm 0.56^{*}$ & $-5.37 \%$ \\
\hline $77.33 \pm 1.02$ & $76.50 \pm 1.02$ & $74.17 \pm 1.08$ & $75.17 \pm 1.05$ & $-2.79 \%$ \\
\hline $82.50 \pm 0.67$ & $71.00 \pm 0.58^{\star \star \star}$ & $65.83 \pm 0.95^{\star \star \star}$ & $63.67 \pm 0.42^{\star \star \star}$ & $-22.82 \%$ \\
\hline
\end{tabular}

TSAE, aqueous extract of T. serrulatus, TSEO: essential oil of T. serrulatus, GB, Glibenclamide. Each value is presented as mean \pm standard error of the mean $(M \pm S E M), n=6,{ }^{*} p<0.05$, ${ }^{* *} p<0.01,{ }^{* * *} p<0.001,{ }^{*},{ }^{* *},{ }^{* * *}$ statistical significance as compared to the negative control group, "+" percent increase in blood glucose level, "-" percent decrease in blood glucose level.

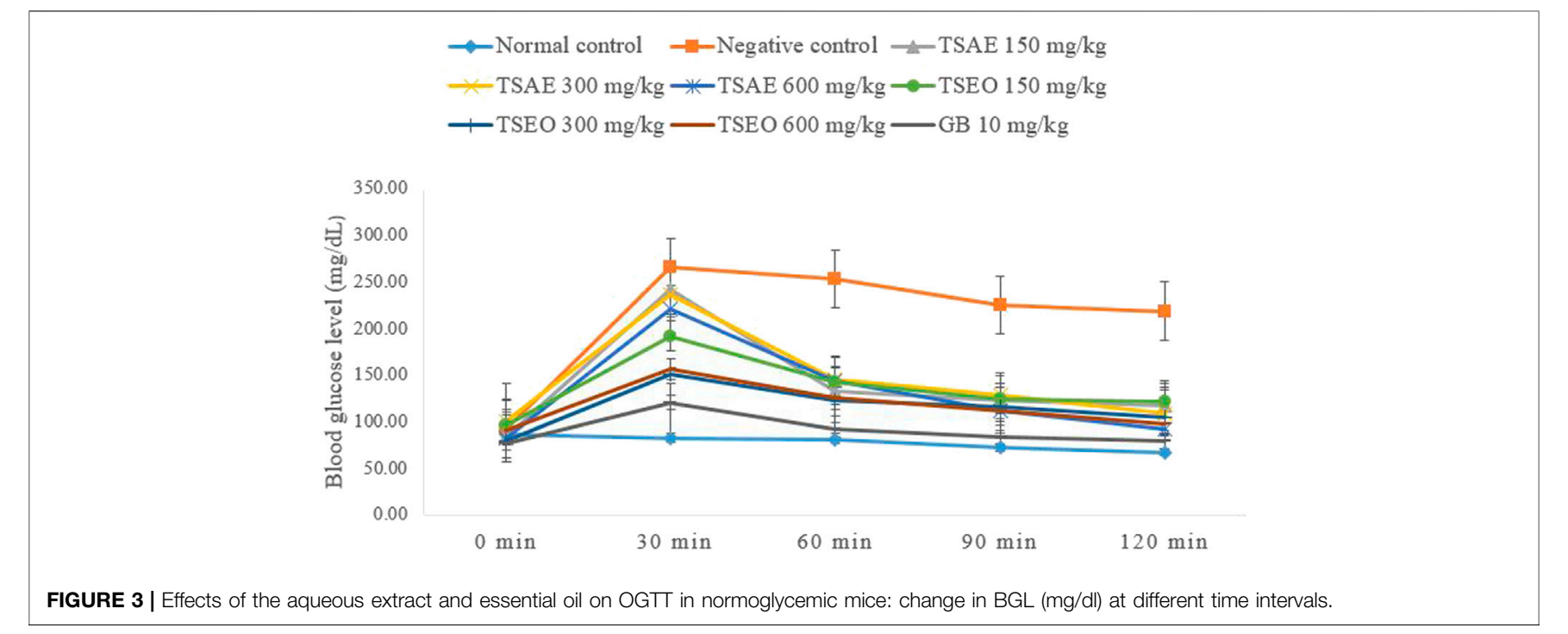

TABLE 6 | Effects of aqueous extract and essential oil of T. serrulatus on FBG level (mg/dl) in STZ induced diabetic mice.

Treatment groups

1 (normal control)
2 (diabetic control)
3 (TSAE $150 \mathrm{mg} / \mathrm{kg}$ )
4 (TSAE $300 \mathrm{mg} / \mathrm{kg})$
5 (TSAE $600 \mathrm{mg} / \mathrm{kg})$
6 (TSEO $150 \mathrm{mg} / \mathrm{kg})$
7 (TSEO $300 \mathrm{mg} / \mathrm{kg})$
8 (TSEO $600 \mathrm{mg} / \mathrm{kg})$
9 (GB $10 \mathrm{mg} / \mathrm{kg})$

Fasting blood glucose level (mg/dl)

\begin{tabular}{cc}
\hline Day $\mathbf{0}$ & Day $\mathbf{7}$ \\
$97.33 \pm 1.15$ & $107.83 \pm 1.33$ \\
$271.67 \pm 2.73$ & $281.00 \pm 5.01$ \\
$292.83 \pm 2.20$ & $291.17 \pm 5.13$ \\
$284.33 \pm 2.09$ & $261.50 \pm 4.87$ \\
$294.17 \pm 2.40$ & $253.00 \pm 5.46^{\star \star}$ \\
$281.67 \pm 3.13$ & $278.00 \pm 6.59$ \\
$289.00 \pm 2.33$ & $274.83 \pm 4.30$ \\
$256.83 \pm 3.36$ & $243.00 \pm 5.98^{\star \star \star}$ \\
$288.00 \pm 5.08$ & $180.33 \pm 4.67^{\star \star \star}$
\end{tabular}

Day 14

$101.67 \pm 1.96$
$268.17 \pm 5.28$
$274.50 \pm 4.46$
$251.83 \pm 5.70$
$251.83 \pm 4.99^{\star \star \star}$
$263.83 \pm 6.45$
$237.67 \pm 12.75^{\star}$
$194.67 \pm 4.19^{\star \star \star}$
$140.83 \pm 6.90^{\star \star \star}$

Day 21

$91.17 \pm 0.95$
$270.69 \pm 6.42$
$249.83 \pm 5.08^{\star}$
$228.83 \pm 6.82^{\star \star \star}$
$164.33 \pm 4.68^{\star \star \star}$
$254.00 \pm 4.82$
$226.17 \pm 5.01^{\star \star \star}$
$177.67 \pm 4.33^{\star \star \star}$
$112.83 \pm 5.42^{\star \star \star}$

$\%$ Change in BGL (day 0-21)

$-6.33 \%$

$-0.36 \%$

$-14.68 \%$

$-19.52 \%$

$-44.14 \%$

$-9.82 \%$

$-21.74 \%$

$-30.82 \%$

$-60.82 \%$

TSAE, aqueous extract of T. serrulatus, TSEO: essential oil of T. serrulatus, GB, glibenclamide. Each value is presented as mean \pm standard error of the mean $(M \pm S E M), n=6,{ }^{*} p<0.05$, ${ }^{* *} p<0.01,{ }^{* * *} p<0.001 *,{ }^{* *},{ }^{* * *}$ statistical significance as compared to the negative control group given $2 \%$ tween $8010 \mathrm{mg} / \mathrm{kg}, "$ "

factors including plant growth, harvest phases, storage, soil, and climatic conditions (Shekarchi et al., 2012). Additionally, isoscutellarein-O-glucuronide (16\%) and luteolin-Oglucuronide $(10 \%)$ were the most prevalent among the other flavone glycosides. These findings are in agreement with previous reported data that showed $O$-glucuronide derivatives of luteolin and other flavone glycosides have also been detected in different Thymus species in significant amounts (Pereira et al., 2013a; Pereira and Cardoso, 2013; Afonso et al., 2017; Afonso et al., 2018).

The principal constituents of the essential oil were the phenolic monoterpene isomers thymol (56.24\%) and carvacrol 
TABLE 7 | Effects of aqueous extract and essential oil of $T$. serrulatus on body weight in STZ induced diabetic mice.

\begin{tabular}{|c|c|c|c|c|c|}
\hline \multirow[t]{2}{*}{ Treatment group } & \multicolumn{4}{|c|}{ Body weight of mice (g) } & \multirow{2}{*}{$\begin{array}{c}\% \text { Change in body } \\
\text { weight }\end{array}$} \\
\hline & Day 0 & Day 7 & Day 14 & Day 21 & \\
\hline 1 (Normal control) & $27.20 \pm 1.14$ & $26.73 \pm 0.90$ & $27.47 \pm 0.91$ & $28.55 \pm 1.10$ & $+4.96 \%$ \\
\hline 2 (Diabetic control) & $24.78 \pm 0.81$ & $23.52 \pm 0.43$ & $21.80 \pm 0.80$ & $19.83 \pm 0.42$ & $-19.97 \%$ \\
\hline 3 (TSAE 150 mg/kg) & $24.82 \pm 0.83$ & $23.85 \pm 2.07$ & $22.50 \pm 0.68$ & $21.08 \pm 0.70$ & $-15.05 \%$ \\
\hline 4 (TSAE 300 mg/kg) & $26.75 \pm 1.84$ & $25.22 \pm 1.54$ & $24.15 \pm 1.89$ & $24.13 \pm 0.87$ & $-9.78 \%$ \\
\hline 5 (TSAE 600 mg/kg) & $24.70 \pm 0.61$ & $24.27 \pm 0.35$ & $23.78 \pm 0.49$ & $24.22 \pm 1.10$ & $-1.96 \%$ \\
\hline 6 (TSEO 150 mg/kg) & $26.12 \pm 1.57$ & $24.77 \pm 1.92$ & $24.17 \pm 1.06$ & $21.30 \pm 0.38$ & $-18.44 \%$ \\
\hline 7 (TSEO 300 mg/kg) & $24.55 \pm 1.57$ & $22.55 \pm 1.25$ & $22.20 \pm 0.58$ & $22.75 \pm 0.64$ & $-7.33 \%$ \\
\hline 8 (TSEO 600 mg/kg) & $23.90 \pm 0.38$ & $22.42 \pm 0.54$ & $22.92 \pm 0.83$ & $23.27 \pm 0.66$ & $-2.65 \%$ \\
\hline 9 (GB 10 mg/kg) & $25.35 \pm 1.68$ & $24.45 \pm 0.63$ & $24.27 \pm 0.39$ & $25.03 \pm 1.50$ & $-1.25 \%$ \\
\hline
\end{tabular}

TSAE, aqueous extract of T. serrulatus, TSEO, essential oil of T. serrulatus, GB, Glibenclamide. Each value is presented as mean \pm standard error of the mean ( $M \pm$ SEM), $n=6$, "+" percent increase in body weight of mice, "-" percent decrease in body weight of mice.

(15.44\%). The findings are in line with a previous study showing that the percent composition of the essential oils of the same plant collected from Ofla and Alamata (South Tigray) were dominated by thymol 49.6 and $65.6 \%$ respectively, but the findings differ from those collected from Yilma Densa (West Gojjam, Amhara) that constituted $80.8 \%$ carvacrol (Damtie et al., 2018). This suggests that the variations in chemical composition of essential oil can be due to differences in geographic and climatic conditions (Asfaw et al., 2000). The essential oil revealed a high amount of thymol therefore it can be classified as thymol chemotype oil (Tirillini et al., 2008). This finding is in agreement with an earlier study which indicated that the essential oils of T. serrulatus belong to the thymol chemotype (Asfaw et al., 2000; Tirillini et al., 2008; Damtie et al., 2017).

Studies show that the increased level of free radicals in the human body is believed to be involved in the pathogenesis of diabetes (Pitocco et al., 2013; Asmat et al., 2016). Thus, the scavenging of these reactive oxygen and nitrogen species is considered to be an effective measure to reduce oxidative stress (Zhang et al., 2015). Thus, phytochemicals with antioxidant properties could play an important role in the prevention and treatment of diabetes (Lin et al., 2016). In this study, both the aqueous extract and the essential oil showed strong radical scavenging activities in the DPPH assay (\%I values of $93.60 \pm$ $0.03 \%$ and $94.51 \pm 0.08 \%$, respectively) as compared to the other assays. Dessalegn and co-researchers also observed strong scavenging effects by various solvent fractions of another thyme specie endemic to Ethiopia (T. schimperi) against DPPH radicals $(92.2 \pm 0.4 \%$ to $96.2 \pm 1.2 \%)$ (Dessalegn et al., 2015).

The free radical scavenging activity of the aqueous extract could be due to the higher content of polyphenolic components like phenolic acids (especially caffeic acid derivatives, mainly salvianolic acids and rosmarinic acid) (Pereira et al., 2013b) and flavones (Catarino et al., 2015). In fact, these classes of phytochemicals have strong antioxidant potential, which are positively correlated with $\mathrm{DPPH} \bullet$ scavenging activity (Wang et al., 2019). On the other hand, the antioxidant capacity of the essential oil might be related to its high content of the phenolic monoterpene thymol. This is consistent with the work of Kulisic and coworkers, who reported a high antioxidant activity for the T. vulgaris essential oil, which is a thymol chemotype oil (Kulisic et al., 2005). The results of this research support the idea that thymol is a stronger antioxidant than carvacrol, due to the greater steric hindering effects of the phenolic group of the latter (Gedikoğlu et al., 2019). It is known that any imbalance between free radicals and antioxidants leads to the condition known as "oxidative stress" that results in the development of a pathological condition in the body, including diabetes. However, please note that even widely used as a fast and reliable parameter to evaluate the general radical scavenging activity of plant extracts (Ullah et al., 2016), in vitro assays lack biological relevance, which must be established through in vivo studies.

The anti-hyperglycemic effects of $T$. serrulatus extracts to substantially reduce the elevated levels of blood glucose may be an essential trigger for the development of normal homeostasis during diabetes and its associated complications. Therefore, both in vitro ( $\alpha$-amylase and $\alpha$-glucosidase inhibitory assays) and in vivo methods were employed to evaluate the antihyperglycemic potential of the plant.

In the hypoglycemic study, we observed that the aqueous extract, at a dose of $300 \mathrm{mg} / \mathrm{kg}$ and $600 \mathrm{mg} / \mathrm{kg}$, significantly lowered BGL compared to negative control in normal mice. Contrary to our results, Shewasinad et al. (2018) reported that the administration of a methanolic leaf extract of T. serpyllum to mice caused no significant hypoglycemic effects in mice at all doses. However, the acute oral administration of aqueous extract of T. serpyllum leaves (at the dose of $500 \mathrm{mg} / \mathrm{kg}$ ) showed significant hypoglycemic effect on normoglycemic mice (Alamgeer et al., 2016), which indicates that the effect might be due to the polar phytochemicals present in the aqueous fraction (Issa and Hussen Bule, 2015). Notably, the tested doses of T. serrulatus essential oil showed no considerable hypoglycemic effect, suggesting that the mechanism of antidiabetic action of the essential oil might differ from that of the aqueous extract and of the standard drug glibenclamide, which acts by stimulating the pancreatic $\beta$-cells to secrete insulin (Tian et al., 1998).

The oral glucose tolerance test, also referred to as the glucose tolerance test, measures the body's ability to metabolize glucose or clear it out of the bloodstream. The aqueous extract, essential oil, and glibenclamide significantly reduced BGL level in mice by $36.99 \% \quad(600 \mathrm{mg} / \mathrm{kg}), \quad 47.19 \% \quad(300 \mathrm{mg} / \mathrm{kg})$, and $60.45 \%$ 
(10 $\mathrm{mg} / \mathrm{kg})$, respectively, as compared to the negative control group. The significant reduction in the BGL registered in the treated groups suggests that both the test substances elicited an increase in glucose utilization and glucose tolerance by the body tissues in mice, which indicates an improved glucose homeostasis (Kabbaoui et al., 2016).

The effect of the relative long-term effect of T. serrulatus on BGL was evaluated using STZ-induced diabetic mice. STZ is a diabetogenic agent used in study on rodents (Wu et al., 2015; Radenković et al., 2016) that destructs the pancreatic $\beta$-cells, resulting in insufficient insulin secretion. STZ-induced diabetes is reported to resemble the human DM, which is manifested by hyperglycemia, glycosuria, polyphagia, polydipsia, hypercholesterolemia, and body weight loss, which was also observed in the experimentally induced animals in our study (Hammeso et al., 2019).

The aqueous extract at the dose of $600 \mathrm{mg} / \mathrm{kg}$ was found to have maximum antihyperglycemic activity (44.14\%), followed by the essential oil $(30.82 \%)$ at the same dose level. This may be explained by the fact that, the test samples are known to exhibit their maximum potential effect at the highest dosage with time against STZ induced diabetes (Rajendiran et al., 2019). Also, these findings are in agreement with the previous reports on antihyperglycemic properties of other Thymus species (Benkhayal et al., 2010b; Kabbaoui et al., 2016; Shewasinad et al., 2018). In this sense, the antihyperglycemic properties of the aqueous extract and essential oil of the plant may be related to the presence of high concentration plant secondary metabolites, especially phenolic acids and other polyphenols (in the aqueous extract), and isomeric phenolic monoterpenes thymol and carvacrol in the essential oil (Çam et al., 2017).

Mice with severe hyperglycemia tend to lose a large percentage of their weight after injection of STZ (Ye, et al., 2011). The aqueous extract and essential oil at $600 \mathrm{mg} / \mathrm{kg}$ dose level significantly prevented weight loss in mice $(-1.96 \%$ and $-2.65 \%$, respectively) comparable to glibenclamide $(-1.25 \%)$. Similar findings were also observed on the aqueous leaf extract of $T$. satureioides at $500 \mathrm{mg} / \mathrm{kg}$ body weight (Kabbaoui et al., 2016). Some studies suggest that increase in body weight could be attributed to the protective effect of the plant extract against degradation of structural proteins, lipids, and muscle wasting, possibly due to improvement of glycemic control via enhancement of insulin secretion or/and action (Kumar et al., 2014; Emiru et al., 2020).

Regarding the in vitro carbohydrate digestive enzyme inhibitory studies, the essential oil showed potent $a$-amylase inhibitory activity $\left(\mathrm{IC}_{50}=0.01 \pm 0.00 \mathrm{mg} / \mathrm{ml}\right)$ as compared to the antidiabetic drug acarbose $\left(\mathrm{IC}_{50}=0.05 \pm 0.02 \mathrm{mg} / \mathrm{ml}\right)$ and the aqueous extract $\left(\mathrm{IC}_{50}=24.47 \pm 0.29 \mathrm{mg} / \mathrm{ml}\right)$. Likewise, the essential oil also demonstrated the highest a-glucosidase inhibitory $\left(\mathrm{IC}_{50}=0.11 \pm 0.01 \mathrm{mg} / \mathrm{ml}\right)$ activity. Previous studies showed a similar trend in terms of a-glucosidase inhibitory activity of T. albicans, T. carnosus and T. mastichina essential oils (Aazza et al., 2016). On the other hand, the aqueous extract revealed better inhibitory activity against $\alpha$-glucosidase (about 10 times greater) than the $\alpha$-amylase inhibitory activity. Therefore, the antihyperglycemic effect of the aqueous extract could be partly associated with its ability to inhibit a-glucosidase, which delays the postprandial rise in blood glucose by retarding the digestion of carbohydrate (Al-Hajj et al., 2016). A more effective digestive enzyme inhibitor is expected when it shows mild inhibitory activity for $a$-amylase but strongly inhibit a-glucosidase enzyme as intestinal disorders such as diarrhea, abdominal pain, and flatulence occur as result of complete inhibition of a-amylase enzyme. This occurs because the starch undigested by the enzyme is used by the intestinal microflora, resulting in gas formation (Cho et al., 2011). These are important findings open up a possibility of the hypoglycemic activity of T. serrulatus to control postprandial hyperglycemia via the inhibition carbohydrate digestive enzymes that offer an attractive strategy by delaying glucose absorption and which can potentially slow down the progression of diabetes.

It is argued that postprandial plasma glucose level is more reflective of glucose control than fasting plasma glucose, thus this may be more useful for monitoring diabetic patients (Shahram and Nargess, 2008; Min Park et al., 2009; Lim et al., 2017). The elevated postprandial glucose level is considered an independent risk factor for the development of macrovascular complications associated with diabetes and impaired glucose tolerance. It is also been linked with cardiovascular complications despite the HbAlc values being in the non-diabetic range (Aravind et al., 2015).

Oxidative stress results from an increased level of reactive oxygen species in the body, which are believed to be involved in the pathogenesis of diabetes (Kaneto et al., 2010). Hence, phytochemicals with antioxidant activity can play a significant role in the treatment of diabetes related disorders (Catarino et al., 2015). Another approach to treat hyperglycemic condition is to use drugs that lower the glucose absorption by competitively inhibiting intestinal carbohydrate hydrolyzing enzymes and to decrease inflammatory conditions involved in the pathology of type 2 diabetes (Ota and Ulrih, 2017). Further, the phytochemicals present in the plant may also have the properties to increase secretion of insulin by stimulating or regenerating the $\beta$-cells of islets of Langerhans, which may finally improve the activity of carbohydrate metabolizing enzymes toward the reestablishment of normal BGL (Oh, 2015). For instance, phenolic acids like rosmarinic acid, one of the main components of the aqueous extract, is proven to enhance glucose utilization and insulin sensitivity beyond its antioxidant activity (Runtuwene et al., 2016). The antidiabetic prospective associated with flavones including apigenin and luteolin glycosides are known to enhance insulin action, augment the expression and transcriptional activation of PPAR $\gamma$ (peroxisome proliferator-activated receptor gamma) target genes, reduce oxidative stress and inflammation in muscle and promote translocation of GLUT4 (Hossain et al., 2016). Although the antidiabetic effect of thymol and its underlying mechanism of action needs to be furthered explored, it has potential as an anti-hyperglycemic agent by improving insulin resistance in diabetic mice (Saravanan and Pari, 2015).

Hyperglycemia induced oxidative stress via mitochondrial electron-transport chain and subsequent activation of the inflammatory response are considered to be major contributor to diabetes related disorders (Santilli et al., 2015). Therefore, 
phenolic compounds such as phenolic acids and flavonoids, as antioxidants, have a beneficial role in preventing and improving vascular diabetic complications (Aryaeian et al., 2017) and enhance diabetic wound healing process (Thent and Latiff, 2017). Phytochemicals with antioxidant activity were also proven to revert atherosclerotic cardiovascular complications such as coronary artery diseases by reducing the elevated serum lipid levels in diabetic patients (Bacanli et al., 2019; Hirano, 2018).

\section{CONCLUSION}

In conclusion, this study suggested that both the aqueous extract and essential oil of $T$. serrulatus have potential antioxidant scavenging ability. Moreover, the two T. serrulatus samples hold potency to inhibit $\alpha$-amylase and $\alpha$-glucosidase enzymes, which are key metabolic enzymes and targets for diabetes treatment. In addition, the results also demonstrated that $T$. serrulatus was capable of inducing significant antihyperglycemic activities in normoglycemic and STZ induced diabetic mice, as well as of effectively preventing the anticipated body weight loss of the diabetic mice. The overall results suggest that the presence of phenolic constituents in the test samples increased the blood glucose lowering effects of $T$. serrulatus, although further analysis using specific metabolites of these compounds must be tested in order to consolidate such theory. Note also that although the extract and essential oil showed strong radical scavenging activity in different chemical assays, their effectiveness still needs to be evaluated in animal models. We also recommend further investigation to evaluate the anti-diabetic effect of the plant extract and essential oil at lower dose levels to translate the effect closer to a therapeutic value for human studies.

\section{DATA AVAILABILITY STATEMENT}

The raw data supporting the conclusions of this article will be made available by the authors, without undue reservation.

\section{REFERENCES}

Aazza, S., El-Guendouz, S., Miguel, M. G., Antunes, M. D., Faleiro, M. L., Correia, A. I., et al. (2016). Antioxidant, Anti-inflammatory and Anti-hyperglycaemic Activities of Essential Oils from Thymbra Capitata, Thymus Albicans, Thymus Caespititius, Thymus Carnosus, Thymus Lotocephalus and Thymus Mastichina from Portugal. Nat. Prod. Commun. 11, 1029-1038. doi:10.1177/ 1934578X1601100739

Afonso, A. F., Pereira, O., Neto, R., Silva, A., and Cardoso, S. (2017). Healthpromoting Effects of Thymus Herba-barona, Thymus Pseudolanuginosus, and Thymus Caespititius Decoctions. Int. J. Mol. Sci. 18, 1879. doi:10.3390/ ijms18091879

Afonso, A. F., Pereira, O. R., and Cardoso, S. M. (2020). Health-promoting Effects of Thymus Phenolic-Rich Extracts: Antioxidant, Anti-Inflammatory and Antitumoral Properties. Antioxidants. 9, 814. doi:10.3390/antiox9090814

Afonso, A. F., Pereira, O. R., Válega, M., Silva, A. M. S., and Cardoso, S. M. (2018). Metabolites and Biological Activities of Thymus Zygis, Thymus Pulegioides, and

\section{ETHICS STATEMENT}

The animal study was reviewed and approved by Health Research Ethics Review Committee (ERC1550/2018), College of Health Sciences, Mekelle University.

\section{AUTHOR CONTRIBUTIONS}

TH conceived idea, TH and AK designed the experiment. TH, SC, $\mathrm{Cd}, \mathrm{OP}, \mathrm{EP}, \mathrm{MV}, \mathrm{LN}$ group and AA performed the experiments. $\mathrm{TH}, \mathrm{AK}$, and GP analyzed the data. TH wrote the manuscript. SC, $\mathrm{Cd}, \mathrm{OP}, \mathrm{GP}$, and AK have done critical revision of the manuscript for important intellectual content. $\mathrm{AK}$ has been the corresponding author throughout the writing process. All authors have contributed to the final version and approved the final manuscript.

\section{FUNDING}

This study was supported by a financial grant obtained from MU-NMBU project of Mekelle University (PG/MSc/MUNMBU/CHS/55/2011) for data collection only.

\section{ACKNOWLEDGMENTS}

Authors acknowledge Mekelle University, Ethiopia for providing necessary facilities and also thank Getinet Masresha, Department of Biology, University of Gondar, Ethiopia for authenticating the plant sample. Thanks are due to University of Aveiro, FCT/ MEC for the financial support to the LAQV-REQUIMTE (UIDB/50006/2020) and CIMO (UIDB/00690/2020), through national funds and where applicable co-financed by the FEDER, within the PT2020 Partnership Agreement. SC thanks the research contract under the project AgroForWealth (CENTRO01-0145-FEDER-000001), funded by Centro 2020, through FEDER and PT 2020.

Thymus Fragrantissimus Grown under Organic Cultivation. Molecules 23, 1-15. doi:10.3390/molecules23071514

Al-Hajj, N. Q., Algabr, M., Sharif, H., Aboshora, W., and Wang, H. (2016). In vitro and In Vivo Evaluation of Antidiabetic Activity of Leaf Essential Oil of Pulicaria Inuloides-Asteraceae. J. Food Nutr. Res. 4, 461-470. doi:10.12691/ jfnr-4-7-8

Alamgeer, Mushtaq, M. N., Bashir, S., Ullah, I., Karim, S., Rashid, M., et al. (2016). Comparative Hypoglycemic Activity of Different Fractions of Thymus Serpyllum L. In Alloxan Induced Diabetic Rabbits. Pak. J. Pharm. Sci. 29, 1483-1488.

American Diabetes Association (2009). Diagnosis and Classification of Diabetes Mellitus. Diabetes care 32 (Suppl. 1Suppl 1), S62-S67. doi:10.2337/dc09-S062

Aravind, S., Saboo, B., Sadikot, S., N Shah, S., Makkar, B., Kalra, S., et al. (2015). Consensus Statement on Management of Post-prandial Hyperglycemia in Clinical Practice in India. J. Assoc. Physicians India 63, 45-58.

Aryaeian, N., Sedehi, S. K., and Arablou, T. (2017). Polyphenols and Their Effects on Diabetes Management: A Review. Med. J. Islam Repub Iran 31, 134. doi:10. 14196/mjiri.31.134 
Asfaw, N., Storesund, H. J., Skattebøl, L., Tønnesen, F., and Aasen, A. J. (2000). Volatile Oil Constituents of Two Thymus Species from Ethiopia. Flavour Fragr J. $\quad 15, \quad 123-125$. doi:10.1002/(SICI)1099-1026(200003/04)15:2<123::AIDFFJ879>3.0.CO;2-8

Asmat, U., Abad, K., and Ismail, K. (2016). Diabetes Mellitus and Oxidative Stress-A Concise Review. Saudi Pharm. J. 24, 547-553. doi:10.1016/j.jsps.2015.03.013

Bacanli, M., Aydın, S., Basaran, N., and Basaran, A. (2019). Effects of Phytochemicals against Diabetes. Adv. Food Nutr. Res. 89, 209-238. doi:10. 1016/bs.afnr.2019.02.006

Benkhayal, F., Al-Gazwi, M., Ramesh, S., and Kumar, S. (2010b). Biochemical Studies on the Effect of Volatile Oil of Thymus Capitatus in Alloxan-Induced Diabetic Rats. Curr. Trends Biotechnol. Pharm. 4, 519-524.

Çam, M., Yildiz, S., Ertas, B., Eda Acar, A., taşkın, T., and Kabasakal, L. (2017). Antidiabetic Effects of Salvia Triloba and Thymus Praecox Subsp. Skorpilii Var. Skorpilii in a Rat Model of Streptozotocin/nicotinamide-Induced Diabetes. Marmara Pharm. J. 21, 818-827. doi:10.12991/mpj.2017.8

Catarino, M. D., Alves-Silva, J. M., Pereira, O. R., and Cardoso, S. M. (2015). Antioxidant Capacities of Flavones and Benefits in Oxidative-Stress Related Diseases. Curr. Top. Med. Chem. 15 (2), 105-119. doi:10.2174/ 1568026615666141209144506

Cho, M., Han, J. H., and You, S. (2011). Inhibitory Effects of Fucan Sulfates on Enzymatic Hydrolysis of Starch. LWT-Food Sci. Technology. 44 (4), 1164-1171. doi:10.1016/J.LWT.2010.09.019

Damtie, D., Braunberger, C., Conrad, J., Mekonnen, Y., and Beifuss, U. (2018). Composition and Hepatoprotective Activity of Essential Oils from Ethiopian Thyme Species (Thymus Serrulatus and Thymus Schimperi). J. Essent. Oil Res. 31, 1-9. doi:10.1080/10412905.2018.1512907

Damtie, D., Mekonnen, Y., and Eyado, A. (2017). Acute Oral Toxicity Study of Thymus Serrulatus and Thymus Schimperi from Ethiopia. Ethiop. J. Sci. Technol. 10, 181. doi:10.4314/ejst.v10i3.3

Damtie, D., and Mekonnen, Y. (2015). Thymus Species in Ethiopia: Distribution, Medicinal Value, Economic Benefit, Current Status and Threatening Factors. Ethiop. J. Sci. Technol. 8, 81-92. doi:10.4314/ejst.v8i2.3

Dessalegn, E., Bultosa, G., Desse Haki, G., and Rupasinghe, H. P. V. (2015). Antioxidant and $\alpha$-amylase Inhibition Activities In Vitro of Various Solvent Extracts of Thymus Schimperi Ronniger. J. Med. Plant Res. 9, 515-524. doi:10. 5897/JMPR2014.5431

Doan, H. V., Riyajan, S., Iyara, R., and Chudapongse, N. (2018). Antidiabetic Activity, Glucose Uptake Stimulation and a-glycosidase Inhibitory Effect of Chrysophyllum Cainito L. Stem Bark Extract. BMC Complement. Altern. Med. 18, 267. doi:10.1186/s12906-018-2328-0

Emiru, Y. K., Periasamy, G., Karim, A., Rehman, N. U., and Ansari, M. N. (2020). Evaluation of In Vitro a-amylase Inhibitory Activity and Antidiabetic Effect of Myrica Salicifolia in Streptozotocin-Induced Diabetic Mice. Pak J. Phar. Sci. 33, 1917-1926. doi:10.36721/PJPS.2020.33.4.SUP.1917-1926.1

European Society of Cardiology (2019). Global Statistics on Diabetes. Available at https://www.escardio.org/Sub-specialty-communities/European-Associationof-Preventive Cardiology-(EAPC)/News/global-statistics-on-diabetes (accessed 9 9, 19).

Gedikoğlu, A., Sökmen, M., and Çivit, A. (2019). Evaluation of Thymus Vulgaris and Thymbra Spicata Essential Oils and Plant Extracts for Chemical Composition, Antioxidant, and Antimicrobial Properties. Food Sci. Nutr. 7, 1704-1714. doi:10.1002/fsn3.1007

Geleta, B., Belete, M., Kebamo, S., Debella, A., Makonnen, E., and Abebe, A. (2015). In vitro vasodilatory Effect of Aqueous Leaf Extract of Thymus Serrulatus on Thoracic Aorta of Guinea Pigs. Asian Pac. J. Trop. Biomed. 5, 15-18. doi:10. 1016/S2221-1691(15)30164-7

Ghasemi Pirbalouti, A., Emami, Z., and Malekpoor, F. (2015). An Overview on Genus Thymus. J. Herb. Drugs 6 (2), 93-100.

Hammeso, W. W., Emiru, Y. K., Ayalew Getahun, K., and Kahaliw, W. (2019). Antidiabetic and antihyperlipidemic activities of the leaf latex extract of Aloe megalacantha baker (Aloaceae) in streptozotocin-induced diabetic model. J. Evid. Based Complementary Altern. Med. doi:10.1155/2019/8263786

Hossain, M. K., Dayem, A. A., Han, J., Yin, Y., Kim, K., Saha, S. K., et al. (2016). Molecular Mechanisms of the Anti-obesity and Anti-diabetic Properties of Flavonoids. Int. J. Mol. Sci. 17 (4), 569. doi:10.3390/ijms17040569

Issa, I. A., and Bule, M. H. (2015). Hypoglycemic Effect of Aqueous and Methanolic Extract of Artemisia Afra on Alloxan Induced Diabetic Swiss
Albino Mice. Evid.-Based Complement. Altern. Med. 2015, 752486. doi:10. $1155 / 2015 / 752486$

Johansen, J. S., Harris, A. K., Rychly, D. J., and Ergul, A. (2005). Oxidative Stress and the Use of Antioxidants in Diabetes: Linking Basic Science to Clinical Practice. Cardiovasc. Diabetol. 4, 5. doi:10.1186/1475-2840-4-5

Kabbaoui, M. E., Chda, A., Mejrhit, N., Farah, A., Aarab, L., Bencheikh, R., et al. (2016). Antidiabetic Effect of Thymus Satureioides Aqueous Extract in Streptozotocin-Induced Diabetic Rats. J. Food Nutr. Res. 1, 140-145. doi:10. 22159/ijpps.2016v8i9.12647

Kaneto, H., Katakami, N., Matsuhisa, M., and Matsuoka, T. (2010). Role of Reactive Oxygen Species in the Progression of Type 2 Diabetes and Atherosclerosis. Mediators Inflamm. 2010, 453892. doi:10.1155/2010/453892

Kulisic, T., Radonić, A., and Milos, M. (2005). Antioxidant Properties of Thyme (Thymus Vulgaris L.) and Wild Thyme (Thymus Serpyllum L.) Essential Oils. Ital. J. Food Sci. 17, 315-324.

Kumar, V., Anwar, F., Ahmed, D., Verma, A., Ahmed, A., Damanhouri, Z. A., et al. (2014). Paederia Foetida Linn. Leaf Extract: an Antihyperlipidemic, Antihyperglycaemic and Antioxidant Activity. BMC Comp. Alter. Med. 14, 76. doi:10.1186/1472-6882-14-76

Lanjhiyana, S., Garabadu, D., Ahirwar, D. K., Bigoniya, P., Rana, A. C., and Patra, K. C. (2011). Hypoglycemic Activity Studies on Root Extracts of Murraya Koenigii Root in Alloxan-Induced Diabetic Rats. J. Nat. Prod. Plant Resour. 1 (2), 91-104.

Li, X., He, T., Wang, X., Shen, M., Yan, X., and Fan, S. (2019). Traditional Uses, Chemical Constituents and Biological Activities of Plants from the Genus Thymus. Chem. Biodivers. 16 (9), e1900254. doi:10.1002/cbdv.201900254

Lim, L. L., Brnabic, A. J., Chan, S. P., Ibrahim, L., Paramasivam, S. S., and Ratnasingam, J. (2017). Relationship of Glycated Hemoglobin, and Fasting and Postprandial Hyperglycemia in Type 2 Diabetes Mellitus Patients in Malaysia. J. Diabetes Investig. 8, 453-461. doi:10.1111/jdi.12596

Lin, D., Xiao, M., Zhao, J., Li, Z., Xing, B., and Li, X. (2016). An Overview of Plant Phenolic Compounds and Their Importance in Human Nutrition and Management of Type 2 Diabetes. Molecules 21 (10), 1374. doi:10.3390/ molecules 21101374

Ma, L., Tang, L., and Yi, Q. (2019). Salvianolic acids: potential source of natural drugs for the treatment of fibrosis disease and cancer. Front. Pharmacol. 10, 97. doi:10.3389/fphar.2019.00097

Mancini, E., Senatore, F., Monte, D. Del., Martino, L. De., Grulova, D., Scognamiglio, M., et al. (2015). Studies on Chemical Composition, Antimicrobial and Antioxidant Activities of Five Thymus Vulgaris L. Essential Oils. Molecules 2, 12016-12028. doi:10.3390/molecules200712016

Martins-Gomes, C., Taghouti, M., Schäfer, J., Bunzel, M., Silva, A. M., and Nunes, F. M. (2018). Chemical Characterization and Bioactive Properties of Decoctions and Hydroethanolic Extracts of Thymus Carnosus Boiss. J. Funct. Foods 43, 154-164. doi:10.1016/j.jff.2018.02.012

Melka, A., Makonnen, E., Debella, A., Fekadu, N., and Geleta, B. (2016). Evaluation of Diuretic Activity of Methanol Crude Extract of Thymus Serrulatus Leaves and its Solvent Fraction in Mice. Biol. Med. (Aligarh). 8, 7. doi:10.4172/09748369.1000347

Meresa, A., Gemechu, W., Basha, H., Fekadu, N., Teka, F., and Ashebir, R. (2017). Herbal Medicines for the Management of Diabetic Mellitus in Ethiopia and Eretria Including Their Phytochemical Constituents. Am. J. Adv. Drug Deliv. 5, 040-058. doi:10.21767/2321-547X.1000011

Min Park, J., Yoon Bong, H., Jeong, H., Kyoung Kim, Y., Yeon Kim, J., and Kwon, O. (2009). Postprandial Hypoglycemic Effect of Mulberry Leaf in GotoKakizaki Rats and Counterpart Control Wistar Rats. Nutr. Res. Pract. 3, 272-278. doi:10.4162/nrp.2009.3.4.272

Niculae, M., Hanganu, D., Oniga, I., Benedec, D., Ielciu, I., Giupana, R., et al. (2019). Phytochemical Profile and Antimicrobial Potential of Extracts Obtained from Thymus Marschallianus Willd. Molecules 24, 3101. doi:10.3390/molecules 24173101

Oh, Y. S. (2015). Plant-derived Compounds Targeting Pancreatic Beta Cells for the Treatment of Diabetes. Evid. Based Complement. Alternat Med. 2015, 629863. doi:10.1155/2015/629863

Ota, A., and Ulrih, N. P. (2017). An Overview of Herbal Products and Secondary Metabolites Used for Management of Type Two Diabetes. Front. Pharmacol. 8, 436. doi:10.3389/fphar.2017.00436

Paul, S., Ali, A., and Katare, R. (2020). Molecular Complexities Underlying the Vascular Complications of Diabetes Mellitus - A Comprehensive 
Review. J. Diabetes Complicat. 34, 107613. doi:10.1016/j.jdiacomp.2020. 107613

Pereira, O. R., Catarino, M. D., Afonso, A. F., Silva, A. M. S., and Cardoso, S. M. (2018). Salvia Elegans, Salvia Greggii and Salvia Officinalis Decoctions: Antioxidant Activities and Inhibition of Carbohydrate and Lipid Metabolic Enzymes. Molecules 23 (12), 3169. doi:10.3390/molecules23123169

Pereira, O. R., and Cardoso, S. M. (2013). Overview on Mentha and Thymus Polyphenols. Curr. Anal. Chem. 9 (3), 382-396. doi:10.2174/ 1573411011309030008

Pereira, O. R., Peres, A. M., Silva, A. M. S., Domingues, M. R. M., and Cardoso, S. M. (2013a). Simultaneous Characterization and Quantification of Phenolic Compounds in Thymus X Citriodorus Using a Validated HPLC-UV and ESI-MS Combined Method. Food Res. Int. 52 (2), 1773-1780. doi:10.1016/j. foodres.2013.09.016

Pereira, O. R., Macias, R. I. R., Perez, M. J., Marin, J. J. G., and Cardoso, S. M. (2013b). Protective Effects of Phenolic Constituents from Cytisus Multiflorus, Lamium Album L. And Thymus Citriodorus on Liver Cells. J. Funct. Foods 5 (3), 1170-1179. doi:10.1016/j.jff.2013.03.014

Pitocco, D., Tesauro, M., Alessandro, R., Ghirlanda, G., and Cardillo, C. (2013). Oxidative Stress in Diabetes: Implications for Vascular and Other Complications. Int. J. Mol. Sci. 14, 21525-21550. doi:10.3390/ijms141121525

Radenković, M., Stojanović, M., and Prostran, M. (2016). Experimental Diabetes Induced by Alloxan and Streptozotocin: The Current State of the Art. J. Pharmacol. Toxicol. Methods 78, 13-31. doi:10.1016/j.vascn.2015.11.004

Rajendiran, D., Banu, H., Khan, H., Packirisamy, S., and Gunasekaran, K. (2019). Dose Dependent Antidiabetic Effect of Mimosa Pudica Leaves Extract in Type 2 Diabetic Rat Model. Phar. Innov. J. 8, 1-04.

Runtuwene, J., Cheng, K.-C., Asakawa, A., Amitani, H., Amitani, M., and Morinaga, A. (2016). Rosmarinic Acid Ameliorates Hyperglycemia and Insulin Sensitivity in Diabetic Rats, Potentially by Modulating the Expression of PEPCK and GLUT4. Drug Dis. Deve.l Ther. 10, 2193-2202. doi:10.2147/DDDT.S108539

Sah, S., Sah, M., Juyal, V., and Pandey, S. (2011). Hypoglycemic Activity of Aqueous Extract of Urtica Parviflora Roxb. In Normoglycemic Rats. Int. J. Phytomedicine 2, 47-51. doi:10.5138/ijpm.2010.0975.0185.02009

Salehi, B., Abu-Darwish, M. S., Tarawneh, A. H., Cabral, C., Gadetskaya, A. V., and Salgueiro, L. (2019). Thymus Spp. Plants - Food Applications and Phytopharmacy Properties. Trends Food Sci. Technol. 85, 287-306. doi:10. 1016/j.tifs.2019.01.020

Santilli, F., D'Ardes, D., and Davì, G. (2015). Oxidative Stress in Chronic Vascular Disease: from Prediction to Prevention. Vascul. Pharmacol. 74, 23-37. doi:10. 1016/j.vph.2015.09.003

Saravanan, S., and Pari, L. (2015). Role of Thymol on Hyperglycaemia and Hyperlipidemia in High Fat Diet-Induced Type 2 Diabetic C57BL/6J Mice. Eur. J. Pharmacol. 761, 279-287. doi:10.1016/j.ejphar.2015.05.034

Satoh, T., Igarashi, M., Yamada, S., Takahashi, N., and Watanabe, K. (2015). Inhibitory Effect of Black Tea and its Combination with Acarbose on Small Intestinal a-glycosidase Activity. J. Ethnopharmacol. 161, 147-155. doi:10.1016/ j.jep.2014.12.009

Shahram, H., and Nargess, G. (2008). Relation of Fasting and Postprandial Plasma Glucose to Glycosylated Hemoglobin in Diabetic Patients. Rawal Med. J 33, $12-14$.

Shekarchi, M., Hajimehdipoor, H., Saeidnia, S., Gohari, A. R., and Hamedani, M. P. (2012). Comparative Study of Rosmarinic Acid Content in Some Plants of Labiatae Family. Pharmacogn. Mag. 8, 37-41. doi:10.4103/0973-1296.93316

Shewasinad, A., Bhoumik, D., Hishe, H. Z., and Masresha, B. (2018). Antidiabetic Activity of Methanol Extract and Fractions of Thymus Schimperi Ronniger
Leaves in Normal and Streptozotocin Induced Diabetic Mice. Iranj. Pharmacol. Ther. 16, 1-8.

Shori, A. B. (2015). Screening of Antidiabetic and Antioxidant Activities of Medicinal Plants. J. Integr. Med. 13, 297-305. doi:10.1016/S2095-4964(15) 60193-5

Srinivasan, K., and Ramarao, P. (2007). Animal Models in Type 2 Diabetes Research: an Overview. Indian J. Med. Res. 125, 451-472.

Tian, Y. M., Johnson, G., and Ashcroft, J. H. (1998). Sulfonylureas Enhance Exocytosis from Pancreatic Beta-Cells by a Mechanism that Does Not Involve Direct Activation of Protein Kinase C. Diabetes 47, 1722-1726. doi:10.2337/diabetes.47.11.1722

Tirillini, B., Pellegrino, R. M., Chessa, M., and Pintore, G. (2008). Chemical Composition of Thymus Serrulatus Hochst. Ex Benth. Essential Oils from Ethiopia: A Statistical Approach. Nat. Prod. Commun. 3, 2069-2074. doi:10. 1177/1934578X0800301224

Toelsie, J., Bipat, R., Algoe, M., and Mans, D. (2013). Diabetes Mellitus: Historical Background, Global Aspects, and Impact in Suriname. Acad. J. Sur. 4, 365-371.

Tohidi, B., Rahimmalek, M., and Trindade, H. (2019). Review on Essential Oil, Extracts Composition, Molecular and Phytochemical Properties of Thymus Species in Iran. Ind. Crops. Prod. 134, 89-99. doi:10.1016/j.indcrop.2019.02.038

Ullah, A., Khan, A., and Khan, I. (2016). Diabetes Mellitus and Oxidative Stress--A concise review. Saudi Phar. J. 24, 547-553. doi:10.1016/j.jsps.2015.03.013

Vinholes, J., Grosso, C., Andrade, P. B., Gil-Izquierdo, A., Valentão, P., and Pinho, P. G. (2011). In vitro studies to assess the antidiabetic, anti-cholinesterase and antioxidant potential of Spergularia rubra. Food Chem. 129, 454-462. doi:10. 1016/j.foodchem.2011.04.098

Vinholes, J., Lemos, G., Barbieri, R., Franzon, R., and Vizzotto, M. (2017). In vitro assessment of the antihyperglycemic and antioxidant properties of araçá, butiá and pitanga. Food Biosci. 19, 92-100. doi:10.1016/j.fbio.2017.06.005

Wang, J., Xu, J., Gong, X., Yang, M., Zhang, C., and Li, M. (2019). Biosynthesis, chemistry, and pharmacology of polyphenols from Chinese Salvia species: A Review. Molecules 24, 155. doi:10.3390/molecules 24010155

$\mathrm{Wu}$, J., and Yan, L. J. (2015). Streptozotocin-induced type 1 diabetes in rodents as a model for studying mitochondrial mechanisms of diabetic $\beta$ cell glucotoxicity. Diabetes Metab. Syndr. Obes. 8, 181-188. doi:10.2147/DMSO.S82272

Ye, M., Qiu, T., Wei, P., Chen, W. X., Ye, Y. W., and Lin, Y. R. (2011). Purification, characterization and hypoglycemic activity of extracellular polysaccharides from Lachnum calyculiforme. Carbohydr. Polym. 86, 285-290. doi:10.1016/j. carbpol.2011.04.051

Zarshenas, M. M., and Krenn, L. (2015). A critical overview on Thymus daenensis Celak.: phytochemical and pharmacological investigations. J. Integr. Med. 13, 91-98. doi:10.1016/S2095-4964(15)60166-2

Zhang, Y. J., Gan, R. Y., Li, S., Zhou, Y., Li, A. N., and Xu, D. P. (2015). Antioxidant phytochemicals for the prevention and treatment of chronic diseases. Molecules 20, 21138-21156. doi:10.3390/molecules201219753

Conflict of Interest: The authors declare that the research was conducted in the absence of any commercial or financial relationships that could be construed as a potential conflict of interest.

Copyright $\odot 2021$ Haile, Cardoso, de Oliveira Raphaelli, Pereira, Pereira, Vizzotto, Nora, Asfaw, Periasamy and Karim. This is an open-access article distributed under the terms of the Creative Commons Attribution License (CC BY). The use, distribution or reproduction in other forums is permitted, provided the original author(s) and the copyright owner(s) are credited and that the original publication in this journal is cited, in accordance with accepted academic practice. No use, distribution or reproduction is permitted which does not comply with these terms. 